\title{
Linking variations in sea spray aerosol particle hygroscopicity to composition during two microcosm experiments
}

\author{
Sara D. Forestieri ${ }^{1}$, Gavin C. Cornwell ${ }^{2}$, Taylor M. Helgestad ${ }^{1}$, Kathryn A. Moore ${ }^{2}$ Christopher Lee $^{2}$, \\ Gordon A. Novak ${ }^{3}$, Camille M. Sultana ${ }^{2}$, Xiaofei Wang ${ }^{2}$, Timothy H. Bertram ${ }^{2,3}$, Kimberly A. Prather ${ }^{2,4}$, and \\ Christopher D. Cappa ${ }^{1}$ \\ ${ }^{1}$ Department of Civil and Environmental Engineering, University of California, Davis, CA 95616, USA \\ ${ }^{2}$ Department of Chemistry and Biochemistry, University of California, San Diego, La Jolla, CA 92093, USA \\ ${ }^{3}$ Department of Chemistry, University of Wisconsin, Madison, WI 53706, USA \\ ${ }^{4}$ Scripps Institution of Oceanography, 9500 Gilman Drive, La Jolla, CA 92093, USA \\ Correspondence to: Christopher D. Cappa (cdcappa@ucdavis.edu)
}

Received: 14 January 2016 - Published in Atmos. Chem. Phys. Discuss.: 25 January 2016

Revised: 20 June 2016 - Accepted: 21 June 2016 - Published: 22 July 2016

\begin{abstract}
The extent to which water uptake influences the light scattering ability of marine sea spray aerosol (SSA) particles depends critically on SSA chemical composition. The organic fraction of SSA can increase during phytoplankton blooms, decreasing the salt content and therefore the hygroscopicity of the particles. In this study, subsaturated hygroscopic growth factors at $85 \%$ relative humidity $(\mathrm{GF}(85 \%))$ of predominately submicron SSA particles were quantified during two induced phytoplankton blooms in marine aerosol reference tanks (MARTs). One MART was illuminated with fluorescent lights and the other was illuminated with sunlight, referred to as the "indoor" and "outdoor" MARTs, respectively. Optically weighted GF( $85 \%$ ) values for SSA particles were derived from measurements of light scattering and particle size distributions. The mean optically weighted SSA diameters were 530 and $570 \mathrm{~nm}$ for the indoor and outdoor MARTs, respectively. The $\mathrm{GF}(85 \%)$ measurements were made concurrently with online particle composition measurements, including bulk composition (using an Aerodyne high-resolution aerosol mass spectrometer) and single particle (using an aerosol time-of-flight mass spectrometer) measurement, and a variety of water-composition measurements. During both microcosm experiments, the observed optically weighted $\mathrm{GF}(85 \%)$ values were depressed substantially relative to pure inorganic sea salt by 5 to $15 \%$. There was also a time lag between $\mathrm{GF}(85 \%)$ depression and the peak chlorophyll $a$ (Chl $a$ ) concentrations by either 1 (indoor MART) or 3-to-6 (outdoor MART) days. The fraction
\end{abstract}

of organic matter in the SSA particles generally increased after the Chl $a$ peaked, also with a time lag, and ranged from about 0.25 to 0.5 by volume. The observed depression in the $\mathrm{GF}(85 \%)$ values (relative to pure sea salt) is consistent with the large observed volume fractions of nonrefractory organic matter (NR-OM) comprising the SSA. The $\mathrm{GF}(85 \%)$ values exhibited a reasonable negative correlation with the SSA NR-OM volume fractions after the peak of the blooms (i.e., Chl $a$ maxima); i.e., the $\mathrm{GF}(85 \%)$ values generally decreased when the NR-OM volume fractions increased. The GF( $85 \%)$ vs. NR-OM volume fraction relationship was interpreted using the Zdanovskii-Stokes-Robinson (ZSR) mixing rule and used to estimate the $\mathrm{GF}(85 \%)$ of the organic matter in the nascent SSA. The estimated pure NR$\mathrm{OM} \mathrm{GF}(85 \%)$ values were $1.16 \pm 0.09$ and $1.23 \pm 0.10$ for the indoor and outdoor MARTS, respectively. These measurements demonstrate a clear relationship between SSA particle composition and the sensitivity of light scattering to variations in relative humidity. The implications of these observations to the direct climate effects of SSA particles are discussed.

\section{Introduction}

Aerosols impact climate directly by scattering and absorbing solar radiation and indirectly by modifying cloud properties (IPCC, 2013). Sea spray aerosol (SSA) particles are a major 
source of natural aerosols to the atmosphere and dominate the pre-industrial clear-sky direct radiative effects over the ocean (Haywood et al., 1999). Breaking waves in the ocean entrain air into seawater, leading to the formation of bubbles, which burst at the ocean's surface and produce SSA particles (Lewis and Schwartz, 2004). The climate impacts of SSA particles depend critically on their composition, shape, and size (Carslaw et al., 2013; Pilinis et al., 1995). Given typical size distributions for particles in the marine boundary layer, both the submicron $(300-1000 \mathrm{~nm})$ and supermicron $(\sim 1-$ $5 \mu \mathrm{m})$ size ranges contribute to light scattering, with the relative contributions varying depending on location and conditions (Kleefeld et al., 2002). Under humidified conditions, the size of SSA particles is modified through water uptake and loss, which are strong functions of chemical composition (Saxena et al., 1995). The overall mass of SSA particles is dominated by sodium chloride and other inorganic ions, but organic compounds can also contribute substantially to the total mass, especially in the submicron size regime (Facchini et al., 2008; Keene et al., 2007; O'Dowd et al., 2004). Larger organic-matter-to-salt ratios occur in the submicron mode through the formation of film drops, since surface-active organics can become enriched in the thin film prior to bubble bursting (Skop et al., 1994; Stefan and Szeri, 1999; Tseng et al., 1992), but it has also been shown that supermicron particles can contain organic and biological markers (Quinn et al., 2015). Since organic compounds are universally less hygroscopic than inorganic sea salt (Petters and Kreidenweis, 2007), their transfer to SSA will lead to less water uptake and, thus, less scattering than in the case of pure inorganic sea salt particles of the same size.

Previous studies have linked the suppression of water uptake of ambient SSA particles to increasing fractions of marine-derived organic matter in the ambient atmosphere (Vaishya et al., 2013; Ovadnevaite et al., 2011; Lawler et al., 2014; Hegg et al., 2008; Zhang et al., 2014). Phytoplankton blooms lead to chemical changes in seawater and serve as a source of particulate and dissolved organic carbon (DOC) to the system, which is then processed by other micro-organisms as part of the microbial loop (Pomeroy et al., 2007). These chemical and biological changes in the seawater can impact SSA particle composition (Prather et al., 2013; Lee et al., 2015; O'Dowd et al., 2004). The organic fraction of SSA particles has been correlated to metrics for high biological activity, such as chlorophyll $a$, in some studies (O'Dowd et al., 2004; Facchini et al., 2008) but not others (Quinn et al., 2014). Some lab studies have observed small depressions in water uptake by SSA particles produced from natural seawater relative to synthetic, inorganic seawater (Sellegri et al., 2008; Modini et al., 2010; Fuentes et al., 2011; Park et al., 2014). However, all of these studies have focused on particles smaller than $\sim 150 \mathrm{~nm}$, for which variations in composition have bigger impacts on cloud condensation nuclei concentrations (Dusek et al., 2006; Farmer et al., 2015). Substantially less is understood about the connections between seawater composition and the water uptake properties of the larger submicron particles that contribute more to light scattering. The connection between biological and chemical characteristics of seawater and the resulting SSA particle composition, and consequently hygroscopicity, has therefore not been fully established.

To better understand the connection between SSA particle composition and water uptake as it relates to light scattering in particular, two microcosm experiments were conducted in July 2014 as part of IMPACTS (Investigation into Marine Particle Chemistry and Transfer Science). Through the addition of light and nutrients, phytoplankton blooms were induced in natural seawater. Marine aerosol reference tanks (MARTs) were used to produce SSA particles via intermittent plunging of a sheet of water, which reproduces the bubble size distribution of whitecaps in the ocean (Lee et al., 2015; Stokes et al., 2013). Studying the SSA particles produced during these microcosm studies can provide insights into the linkage between hygroscopicity of nascent SSA particles and ocean biology in an environment that is isolated from anthropogenic influence or background particles. The simultaneous measurement of submicron SSA particle water uptake and of particle composition here demonstrate that variations in seawater biology and composition influence water uptake by SSA particles.

\section{Methods}

\subsection{MART description and operation}

Two separate experiments were conducted during July 2014 utilizing MARTs. Detailed information on the performance and operation of MARTs can be found in Stokes et al. (2013) and only a brief description will be provided here. SSA particles were generated in an enclosed $210 \mathrm{~L}$ acrylic tank via an intermittent plunging sheet of water operated on a computer-controlled $4 \mathrm{~s}$ on $/ 4 \mathrm{~s}$ off cycle to allow for surface foam evolution and dissipation close to what would be observed for natural whitecaps in the ocean. The plunging cycle creates a constant, reproducible concentration of nascent SSA particles in the $90 \mathrm{~L}$ headspace, with SSA particle size distributions produced in the MARTs generally consistent with those observed for SSA particles from labgenerated breaking waves (Stokes et al., 2013). SSA particles sampled from the MARTs are primary, since the average residence time in the MARTs is much shorter than the timescale required for secondary processing of SSA particles (e.g., heterogeneous gas-phase reactions) (Lee et al., 2015). SSA particles from the headspace were sampled periodically each day by instruments that characterized SSA particle size distributions, composition, and optical and hygroscopic properties. SSA were sampled from the MART headspace and transported through an approximately $2 \mathrm{~m}$ long line of $9.5 \mathrm{~mm}$ conductive tubing into a laminar flow manifold from 
Table 1. Summary of all instrumentation used in this study.

\begin{tabular}{|c|c|c|c|c|c|c|}
\hline $\begin{array}{l}\text { Sampling } \\
\text { group }\end{array}$ & $\begin{array}{l}\text { Group } \\
\text { MART flow } \\
\text { rates }\left(\mathrm{L} \mathrm{min}^{-1}\right) \\
\text { input/output }\end{array}$ & $\begin{array}{l}\text { Group } \\
\text { sampling } \\
\text { duration } \\
\text { (h) }\end{array}$ & $\begin{array}{l}\text { Group } \\
\text { sampling } \\
\text { time after } \\
\text { group no. } 1(\mathrm{~h})\end{array}$ & Instrument/method & Property measured & Reference \\
\hline \multicolumn{7}{|c|}{ Particle measurements } \\
\hline 1 & $4.7 / 3.7$ & 1.5 & 0 & $\begin{array}{l}\text { UC Davis cavity ring- } \\
\text { down spectrometer } \\
\text { (CRD) }\end{array}$ & $\begin{array}{l}\text { Light extinction by dry } \\
(<20 \% \mathrm{RH}) \text { and hu- } \\
\text { midified }(\mathrm{RH} \sim 85 \%) \\
\text { particles }\end{array}$ & $\begin{array}{l}\text { Langridge et } \\
\text { al. (2011); Cappa et } \\
\text { al. (2012) }\end{array}$ \\
\hline 1 & $4.7 / 3.7$ & 1.5 & 0 & $\begin{array}{l}\text { Scanning electrical } \\
\text { mobility spectrometer } \\
\text { (SEMS) }\end{array}$ & $\begin{array}{l}\text { Dry particle mobility } \\
\text { size distributions from } \\
d_{\mathrm{p}, \mathrm{m}}=15 \text { to } 1000 \mathrm{~nm}\end{array}$ & \\
\hline 1 & $4.7 / 3.7$ & 1.5 & 0 & $\begin{array}{l}\text { High-resolution time- } \\
\text { of-flight aerosol } \\
\text { mass spectrometer } \\
\text { (HR-ToF-AMS) }\end{array}$ & $\begin{array}{l}\text { Bulk concentrations of } \\
\text { non-refractory particu- } \\
\text { late components of dry } \\
\text { particles from } d_{\mathrm{va}}=90 \\
\text { to } 700 \mathrm{~nm}\end{array}$ & $\begin{array}{l}\text { Canagaratna et } \\
\text { al. (2007) }\end{array}$ \\
\hline 2 & $3.9 / 2.9$ & 2.0 & 9 & $\begin{array}{l}\text { Aerosol time-of-flight } \\
\text { mass spectrometer } \\
\text { (ATOFMS) }\end{array}$ & $\begin{array}{l}\text { Composition and num- } \\
\text { ber concentration of } \\
\text { dried individual parti- } \\
\text { cles from } d_{\mathrm{va}}=300 \text { to } \\
3000 \mathrm{~nm}\end{array}$ & $\begin{array}{l}\text { Gard et al. (1998); } \\
\text { Pratt et al. (2009) }\end{array}$ \\
\hline 3 & $6.3 / 5.3$ & 1.0 & 4.5 & $\begin{array}{l}\text { Aerodynamic Particle } \\
\text { Sizer (APS) }\end{array}$ & $\begin{array}{l}\text { Dry particle aerody- } \\
\text { namic size distributions } \\
(0.7-20 \mu \mathrm{m})\end{array}$ & \\
\hline \multicolumn{7}{|c|}{ Waterside measurements } \\
\hline & & & & $\begin{array}{l}\text { AquaFluor handheld } \\
\text { portable fluorimeter }\end{array}$ & Chlorophyll $a$ & \\
\hline & & & & $\begin{array}{l}\text { High temperature } \\
\text { combustion }\end{array}$ & $\begin{array}{l}\text { Dissolved organic } \\
\text { carbon }\end{array}$ & \\
\hline & & & & $\begin{array}{l}\text { Epifluorescence } \\
\text { microscopy }\end{array}$ & $\begin{array}{l}\text { Heterotrophic bacteria } \\
\text { concentrations }\end{array}$ & \\
\hline
\end{tabular}

which the instruments sampled. The flow rates to each instrument (or group of instruments) from ports in the manifold differed (e.g., $1 \mathrm{~L} \mathrm{~min}^{-1}$ to the high-resolution timeof-flight aerosol mass spectrometer (HR-ToF-AMS, henceforth AMS) vs. $3 \mathrm{~L} \mathrm{~min}^{-1}$ to the cavity ring-down spectrometer (CRD) + scanning electrical mobility sizer (SEMS)). Although the airstreams were not split isokinetically, the aspiration efficiency was calculated to be near $100 \%$ for the size range of particles sampled here (Kulkarni et al., 2011). Thus, the different instrument groups sampled similar particle populations from the manifold. Due to the limited headspace volume and flow restrictions, not all instruments in this study could sample simultaneously. During individual sampling periods, only a subset of the full instrument suite sampled from the MARTs. The flow rate of zero air going into the MART and the flow being pulled from the MART by the instruments, as well as sampling times for each group of instruments, are provided in Table 1. The flow into the MART was always $1 \mathrm{~L} \mathrm{~min}^{-1}$ greater than the combined in- strument pull to ensure positive pressure in the headspace, which eliminated possibility of sampling of room air. The shape of the measured particle size distributions was relatively independent of flow rate for the range of flow rates considered while sampling from the MARTs, although the residence time of individual particles decreases as the flow rate increases (Stokes et al., 2013). The air pushed into the MART was produced by a zero-air generator (Sabio Instruments, Model 1001), with air flow controlled by a mass flow controller. The excess flow was released through a vent on the MART. The different flow rates through the MART and through the sample tubing for each sampling configuration led to some differences in the size distribution sampled by the downstream instrumentation.

The procedure for inducing phytoplankton blooms inside of the MARTs will be briefly described here; further general details can be found in Lee et al. (2015). The MARTs were filled with $\sim 120 \mathrm{~L}$ of seawater each collected from the Scripps Institution of Oceanography (SIO) pier in La Jolla, 
Table 2. Seawater conditions at the time of collection.

\begin{tabular}{llrrrr}
\hline Date & Time & Chlorophyll $a\left(\mathrm{\mu g} \mathrm{L}^{-1}\right)$ & Water temp. $\left({ }^{\circ} \mathrm{C}\right)$ & Pressure (dbar) & Salinity (PSU) \\
\hline 8 July & $12: 00$ & 0.998 & 23.1214 & 3.389 & 33.546 \\
19 July & $12: 00$ & 2.171 & 20.7463 & 3.567 & 33.6051 \\
\hline
\end{tabular}

California, USA $\left(32^{\circ} 51^{\prime} 56.8^{\prime \prime} \mathrm{N}, 117^{\circ} 15^{\prime} 38.48^{\prime \prime} \mathrm{W}\right)$. Debris and zooplankton were filtered out of the seawater with $50 \mu \mathrm{m}$ mesh. Phytoplankton growth was induced by exposure to artificial or natural light and the addition of growth media, which is described further in Lee et al. (2015). The two independent MART experiments will be referred to, according to the MART location during the growth phase, as either "indoor" or "outdoor". The indoor MART was illuminated using $5700 \mathrm{~K}$ full spectrum lights, while the outdoor MART was illuminated with sunlight. A key difference between these two experiments is the intensity of the photosynthetically active radiation (PAR) during growth. The PAR was much greater for the outdoor MART compared to the indoor MART (PAR 1000-1500 $\mu \mathrm{E} \mathrm{m}^{-2} \mathrm{~s}^{-1}$ (Bouvet et al., 2002) vs. $\sim 70 \mu \mathrm{E} \mathrm{m}^{-2} \mathrm{~s}^{-1}$ ), which likely resulted in a much larger peak Chl $a$ concentration for the outdoor MART, $51 \mu \mathrm{g} \mathrm{L}^{-1}$ (outdoor) vs. $10 \mu \mathrm{g} \mathrm{L}^{-1}$ (indoor). An additional difference between the two microcosms was that the seawater was collected on different days: 8 July for the indoor MART and 19 July for the outdoor MART. The conditions of the seawater at time of collection are detailed in Table 2.

On 9 July, particles from the indoor MART were sampled immediately following nutrient addition. Further sampling was delayed until chlorophyll $a(\mathrm{Chl} a)$ concentrations exceeded approximately $12 \mu \mathrm{g} \mathrm{L}{ }^{-1}$, which occurred 7 days after nutrient addition. (The same seawater as used in the indoor MART was added to a separate MART and sampled immediately after collection and before nutrient addition. However, the resulting particle size distribution from this MART differed substantially from those measured from the indoor MART, with a much greater contribution of large particles. Thus, the measurements from this separate MART are not directly comparable to the measurements from the indoor MART and are not considered further.) The outdoor MART was only sampled after $\mathrm{Chl} a$ concentrations exceeded approximately $12 \mu \mathrm{g} \mathrm{L}^{-1}$, which occurred 3 days after nutrient addition. This delay in sampling from when the water and nutrients were first added to the MARTs is necessary because the plunging process can lead to lysis of the phytoplankton cells during this vulnerable growth period, which will inhibit phytoplankton growth (Lee et al., 2015). Ultimately, SSA from the initially collected water from the indoor MART was sampled on $9 \mathrm{July}$, and subsequent sampling commenced periodically from 19 July through 31 July, i.e., beginning 11 days after the water was collected. Sampling from the outdoor MART did not commence until 22 July, continuing through 1 August. During the growth period and the off-sampling periods, air was gently bubbled through the tank to provide aeration. Sampling from the MARTs was performed daily once the threshold $\mathrm{Chl} a$ concentrations were reached.

\subsection{Instrumentation}

A variety of online and offline measurements were made to characterize water composition and particles generated within the MARTs. A general sampling schematic is shown in Fig. 1 and a list of the instrumentation used is given in Table 1 . As only a limited number of instruments were able to sample concurrently from the MART due to flow limitations, the individual sampling configurations (i.e., groupings of instruments sampling at the same time) are indicated; three specific instrument groupings are considered. The sampling times of each group relative to Group 1 are listed in Table 1 and a more detailed schematic of Group 1 optical and sizing measurements is provided in Fig. S1 in the Supplement. (The specific timing was dictated by the broader goals of IMPACTS.) A general description of the key instrumentation used as part of this study is provided below. Group 1 sampled for $1.5 \mathrm{~h}$, Group 2 sampled for $2 \mathrm{~h}$, and Group 3 sampled for $1 \mathrm{~h}$ each day that sampling was conducted.

\subsubsection{Online particle measurements}

Size distributions for dried particles (relative humidity $(\mathrm{RH})<20 \%$ ) were measured with an SEMS (BMI, model 2002), and an aerodynamic particle sizer (APS; TSI Inc., model 3321). The SEMS combines a differential mobility analyzer (DMA) and a mixing condensation particle counter to characterize particles according to their mobility diameter $\left(d_{\mathrm{p}, \mathrm{m}}\right)$. The APS characterizes particles according to their aerodynamic diameter $\left(d_{\mathrm{p}, \mathrm{a}}\right)$. The SEMS characterized particles over the range $10 \mathrm{~nm}<d_{\mathrm{p}, \mathrm{m}}<1900 \mathrm{~nm}$ and the APS over the range $0.7 \mu \mathrm{m}<d_{\mathrm{p}, \mathrm{a}}<20 \mu \mathrm{m}$. The SEMS size distributions were corrected for the influence of multiply charged particles using software provided by the manufacturers. No diffusion correction was performed, which has negligible influence on this study because the smallest particles $(<100 \mathrm{~nm})$, which are sensitive to diffusion corrections, contribute negligibly to the observed scattering. The APS had a time resolution of $1 \mathrm{~min}$, while the SEMS had a time resolution of $5 \mathrm{~min}$ and the APS distributions were accordingly averaged to $5 \mathrm{~min}$ to facilitate generation of a merged size distribution. The SEMS and APS distributions were merged using the SEMS distribution up to $1 \mu \mathrm{m}$ and the ( $d_{\mathrm{p}, \mathrm{m}}$ equivalent) APS distribu- 


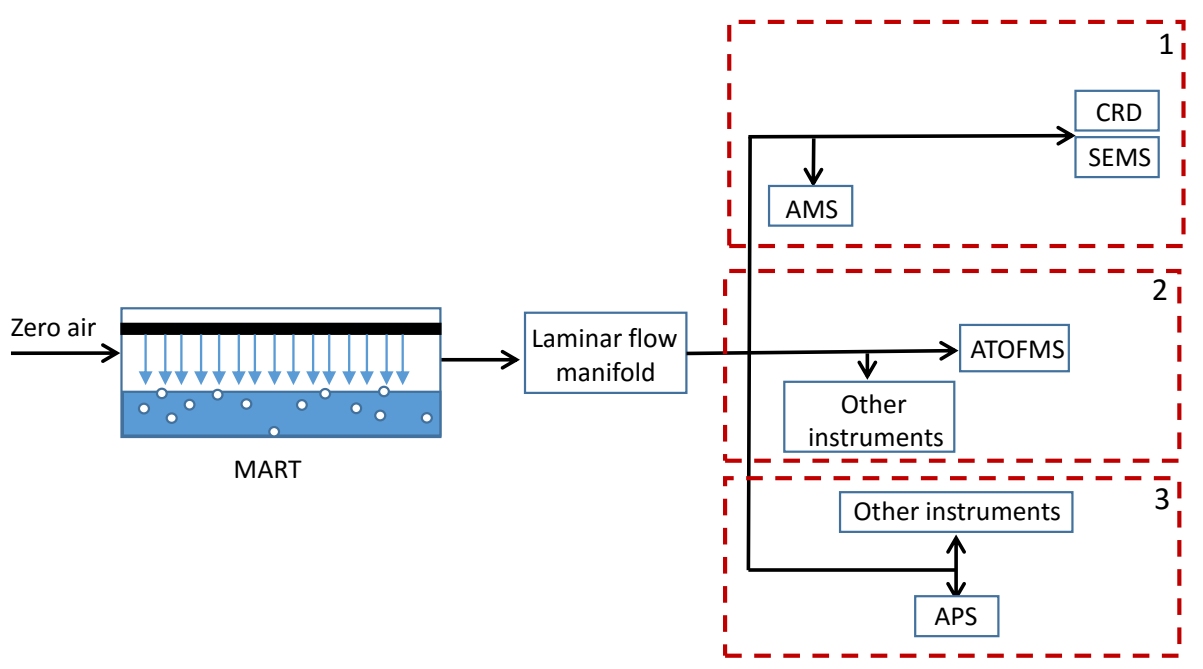

Figure 1. Experimental schematic for MART sampling during the IMPACTS 2014 study, with boxes labeled 1, 2, and 3 corresponding to different sampling configurations.

tion at larger diameters. The APS $d_{\mathrm{p}, \mathrm{a}}$ values were converted to mobility equivalent values assuming a particle density of $1.8 \mathrm{~g} \mathrm{~cm}^{-3}$.

The hygroscopicity of the SSA particles was characterized through simultaneous measurement of light extinction coefficients $\left(b_{\text {ext }}\right)$ for particles that were either dried to $\mathrm{RH}<20 \%$ ("dry") or humidified to $\mathrm{RH} \sim 85 \%$ ("wet") using the UC Davis CRD (Langridge et al., 2011; Cappa et al., 2012). Light absorption by the SSA particles was negligible, and thus extinction is equal to scattering, i.e., $b_{\text {ext }}=b_{\text {sca }}$. The dry particle measurements were made at wavelengths of 532 and $405 \mathrm{~nm}$, while the wet particle measurements were made only at $532 \mathrm{~nm}$. It should be noted that the humidified particle stream was generated without first drying the particles, and thus it is unlikely that the sampled particles had effloresced. Humidification was achieved by passing the particles through a Nafion humidifier (Perma Pure, MD-110-12) while drying was achieved by passing the particles through a diffusion denuder filled with Drierite. Both the humidifier and drier were oriented vertically to prevent differential losses due to sedimentation, which could bias the measurements. The fundamental performance of the CRD method for wet particles is the same for dry particles, but variations and uncertainty in the RH contribute to the uncertainty in the measured $b_{\text {ext }}$. The RH for the humidified channel varied between 80 and $87 \%$ due to challenges in maintaining a constant temperature in the open-air Scripps Hydraulics Lab; these variations are accounted for in the analysis as described below. The RH of the air was measured directly in the CRD cells using RH probes (Vaisala, HMP50) that were calibrated against saturated salt solutions. The wet (high RH) and dry (low RH) particle measurements are combined to provide a characterization of the extent of water uptake at a given $\mathrm{RH}$, which causes particles to grow through the parameter $f(\mathrm{RH})$, where

$f(\mathrm{RH})=\frac{b_{\text {ext }}\left(\mathrm{RH}_{\text {high }}\right)}{b_{\text {ext }}\left(\mathrm{RH}_{\text {low }}\right)}=\frac{b_{\text {sca }}\left(\mathrm{RH}_{\text {high }}\right)}{b_{\text {sca }}\left(\mathrm{RH}_{\text {low }}\right)}$.

The parameter $f(\mathrm{RH})$ is $\mathrm{RH}$ specific and is most appropriate when $\mathrm{RH}_{\text {low }}$ is sufficiently low that there is little, if any, particle-phase water. The accuracy of the $f(\mathrm{RH})$ measurements, as well as the conversion to equivalent growth factors (GFs, Sect. 2.2.3), was tested through measurements made using sodium chloride and ammonium sulfate particles that were generated using an atomizer.

The CRD (and SEMS) alternated between sampling behind a $\mathrm{PM}_{2.5}$ cyclone and with no explicit size cut (referred to as $\left.\mathrm{PM}_{\text {all }}\right)$ every $10 \mathrm{~min}$ to try and determine $f(\mathrm{RH})$ and GF values separately for smaller and larger particles. Note that particles were sampled through the $\mathrm{PM}_{2.5}$ cyclone prior to being dried ( $\mathrm{RH} \sim 70 \%)$ and thus the effective size cut for the subsequently dried particles is somewhat less than $2.5 \mu \mathrm{m}$, depending on the exact water content of the particles at $70 \% \mathrm{RH}$. Since the measured size distributions indicate minimal contributions from particles with $d_{\mathrm{p}, \mathrm{a}}>2.5 \mu \mathrm{m}$, the $\mathrm{PM}_{2.5}$ and $\mathrm{PM}_{\text {all }}$ measurements will generally be considered together.

An aerosol time-of-flight mass spectrometer (ATOFMS) (Gard et al., 1998; Pratt et al., 2009) was used to characterize the composition of individual dried SSA particles with vacuum aerodynamic diameters $\left(d_{\mathrm{va}}\right)$ from $\sim 300 \mathrm{~nm}$ to $3 \mu \mathrm{m}$, with the highest transmission and sampling of particles with $d_{\mathrm{va}} \sim 1-2 \mu \mathrm{m}$ (Wang et al., 2015). The ATOFMS single particle spectra have been analyzed using a statistical clustering algorithm (ART-2a) that groups particles with similar spectra together (Zhao et al., 2008). Five particle mass spectra categories were generated and are described as sea salt (SS), salt mixed with organic carbon (SSOC), predominately organic 
carbon (OC), containing a large iron peak $(\mathrm{Fe})$, and containing a large magnesium peak (Mg) (Lee et al., 2015; Sultana et al., 2016; Wang et al., 2015). A campaign-average spectrum for each category is shown in Fig. S2. The combination of the aerodynamic lens transmission and the input particle size distribution determines the particular weighting of the average fractions of the ATOFMS particle types (see Fig. S3); in this study, the results are for the sampling-weighted average, which corresponds approximately to a sampling-weighted average $d_{\mathrm{va}}=1.5 \mu \mathrm{m}$.

An Aerodyne AMS quantified mass concentrations of non-refractory (NR) components of dried SSA particles, in particular NR organic matter (NR-OM) but also other non-refractory (NR-PM) components (Canagaratna et al., 2007). NR-PM species are defined as those that volatilize at $\sim 600^{\circ} \mathrm{C}$ on a timescale of a few seconds under vacuum $\left(10^{-4}\right.$ torr) conditions. No cyclone was used in front of the AMS, and thus the size range of sampled SSA particles was determined by the size-dependent transmission of the aerodynamic lens, which nominally allowed for quantitative sampling of particles with $d_{\mathrm{va}}$ between 90 and $700 \mathrm{~nm}(50 \%$ cut points at $\sim 40 \mathrm{~nm}$ and $\sim 1$ micron), although some fraction of even larger particles were characterized (Wang et al., 2015). The AMS data were analyzed using the SQUIRREL toolkit. The high-resolution mass spectra were analyzed using the PIKA toolkit to determine $O / C$ atomic ratios for the NR-OM components. The NR-OM fraction of total sampled PM was estimated by normalizing the NR-OM mass concentrations by $\mathrm{PM}_{1}$ concentrations determined from integration of the SEMS particle size distributions using an assumed density of $1.8 \mathrm{~g} \mathrm{~cm}^{-3}$. Since a $d_{\mathrm{va}}$ of $1 \mu \mathrm{m}$ corresponds approximately to a $d_{\mathrm{p}, \mathrm{m}}=560 \mathrm{~nm}$, the use of the SEMS size distribution is appropriate and the derived NR-OM fractions can be considered reflective of the submicron SSA composition. It is important to note that while the temporal trends of the AMS NR-OM/PM ${ }_{1}$ fractions are likely reflective of the general behavior, the absolute values are more difficult to quantify because NR-OM associated with particles containing high sea salt fractions may not be vaporized efficiently by the AMS due to the refractory nature of sea salt (Frossard et al., 2014) and to the susceptibility of SSA particles to particle "bounce" in the AMS. Consequently, the SSA particles, including the NR-OM component, are detected with a collection efficiency (CE) lower than unity (Frossard et al., 2014). One previous study (Ovadnevaite et al., 2012) determined the $\mathrm{CE}$ value for organic-free sea salt sampled when $\mathrm{RH}<70 \%$ is approximately 0.25 . However, they also note that the CE is potentially instrument dependent and, furthermore, may not be applicable to the organic fraction in sea spray particles due to differences in ionization efficiency (which is a component of the overall CE) (Ovadnevaite et al., 2012). It is also possible that the $\mathrm{CE}$ differs between particles that have differing relative amounts of OM and sea salt. Despite such uncertainties in quantification of NR-OM by the AMS for sea spray particles, the NR-OM mass concentrations for the sam- pled SSA particles were determined in this study assuming $\mathrm{CE}=0.25$. The measured NR-OM mass concentrations were used to calculate NR-OM volume concentrations, assuming a density $(\rho)$ of $1.0 \mathrm{~g} \mathrm{~cm}^{-3}$. A value of $1.0 \mathrm{~g} \mathrm{~cm}^{-3}$ for $\rho_{\mathrm{OM}}$ is consistent with that of fatty acids $\left(\rho<1 \mathrm{~g} \mathrm{~cm}^{-3}\right)$, which are a significant fraction of marine-derived OM (Cochran et al., 2016; Mochida et al., 2002). However, this value serves as a lower bound for $\rho_{\mathrm{OM}}$ because $\mathrm{OM}$ with higher densities, such as sugars $\left(\rho \sim 1.7 \mathrm{~g} \mathrm{~cm}^{-3}\right)$, has also been observed in SSA (Quinn et al., 2015). The NR-OM volume fractions of $\operatorname{SSA}\left(\varepsilon_{\text {org }}\right)$ were calculated as the ratio between the observed NR-OM volume concentrations and the integrated total particle volume concentrations from the size distribution measurements. Given the use of a lower-limit value for $\rho_{\mathrm{OM}}$ the $\varepsilon_{\text {org }}$ are likely upper limits (not accounting for uncertainty in the assumed $\mathrm{CE}$ ).

\subsubsection{Optical closure methods}

The $f(\mathrm{RH})$ values measured using the CRD instrument have been used to determine optically weighted physical GFs. For particles of a given size, the GF is defined as

$\mathrm{GF}(\mathrm{RH})=\frac{d_{\mathrm{p}}\left(\mathrm{RH}_{\text {high }}\right)}{d_{\mathrm{p}}\left(\mathrm{RH}_{\text {low }}\right)}$,

where $d_{\mathrm{p}}$ is the geometric particle diameter, which is equivalent to $d_{\mathrm{p}, \mathrm{m}}$ for spherical particles. For clarity, in this work the optically weighted GF will be indicated simply as GF, while size-specific GF values will be indicated as $\mathrm{GF}_{x}$. SSA particle composition can vary with size (e.g., O'Dowd et al., 2004 ), and thus $\mathrm{GF}_{x}$ values may vary with size. The optically weighted GF averages across size-dependent variations in composition and $\mathrm{GF}_{x}$ to focus on the chemical changes that most influence water uptake by the particles that most contribute to light scattering. Unlike $f(\mathrm{RH}), \mathrm{GF}_{x}$ values are independent of the dry particle size (above about $100 \mathrm{~nm}$ diameter) for particles of a given composition. Thus, variations in the optically weighted GF values are driven only by variations in particle composition, specifically variations in the average composition of particles in the size range over which the optical measurements are most sensitive. For the measurements here, the sensitive size range is between about 400 and $800 \mathrm{~nm}$, with particles below $200 \mathrm{~nm}$ contributing almost 0 to the observed scattering (see Sect. 3.1 below).

The observed $f(\mathrm{RH})$ values are converted to $\mathrm{GF}(\mathrm{RH})$ values via optical closure. The optical closure technique uses spherical particle Mie theory calculations and the measured size distributions and $f(\mathrm{RH})$ values to derive equivalent $\mathrm{GF}(\mathrm{RH})$ values. This methodology is described in detail in Zhang et al. (2014). In brief, the dry scattering is first calculated from the measured dry particle size distribution assuming a refractive index of 1.55 (the refractive index for $\mathrm{NaCl}$ ), as

$b_{\text {sca }}=\int \sigma_{\text {sca }}\left(d_{\mathrm{p}, \mathrm{m}}\right) \cdot \frac{\mathrm{d} N}{d \log d_{\mathrm{p}, \mathrm{m}}} d \log d_{\mathrm{p}, \mathrm{m}}$, 
where $\sigma_{\text {sca }}$ is the size-dependent scattering cross section and $d \mathrm{~N} / d \log d_{\mathrm{p}, \mathrm{m}}$ is the number-weighted size distribution. Then, each diameter for the dry distribution is multiplied by a trial value for $\mathrm{GF}(\mathrm{RH})$, the refractive index of the particles is adjusted to account for the resulting volume fraction of water, and the scattering by the resulting "wet" distribution is calculated, from which a theoretical $f(\mathrm{RH})$ value is determined. The calculated $f(\mathrm{RH})$ is compared to the observed $f(\mathrm{RH})$, and if the two do not agree to within 0.01 the trial GF(RH) is increased until closure is obtained. It is assumed that the growth factors are size independent, namely that $\mathrm{GF}_{x}=\mathrm{GF}$ for all $d_{\mathrm{p}}$. Thus, this method retrieves an effective, optically weighted GF value that explains the observed influence of water uptake on light scattering for the sampled size distribution. An alternative approach was considered in which the $\mathrm{GF}_{x}$ were assumed to vary with size, specifically as $\mathrm{GF}_{x}=$ $2.1-b\left(\log (1.8 \mu \mathrm{m})-\log \left(d_{\mathrm{p}, \mathrm{m}}\right)\right)$, and where the value of $b$ was allowed to vary during the optical closure, with the condition that $\mathrm{GF}_{x} \geq 0$. (This expression assumes that particles with $d_{\mathrm{p}, \mathrm{m}}=1.8$ have $\mathrm{GF}_{x}=2.1$, i.e., that of $\mathrm{NaCl}$. The $\mathrm{GF}_{x}$ decrease as size decreases.) The derived $b$ values exhibit a similar temporal dependence as the derived optically weighted GF values. The general conclusions reached in this study are therefore independent of the assumptions made regarding the size-dependent behavior of $\mathrm{GF}_{x}$. Thus, rather than introducing an uncertain functional form, the simpler assumption (namely, size-independent $\mathrm{GF}_{x}$ ) is used here.

As the RH of the humidified channel was not perfectly constant during measurements, the derived individual $\mathrm{GF}(\mathrm{RH})$ values have been adjusted to $85 \%$ by using Eq. (4):

$\frac{\mathrm{RH}}{\exp \left(\frac{A}{d_{\mathrm{d} \cdot \mathrm{GF}(\mathrm{RH})}}\right)}=\frac{\mathrm{GF}(\mathrm{RH})^{3}-1}{\mathrm{GF}(\mathrm{RH})^{3}-(1-\kappa)}$,

where $A$ is a constant, $\mathrm{RH}$ is relative humidity, $d_{\mathrm{d}}$ is the dry particle diameter, and $\kappa$ is the effective hygroscopicity parameter, which is assumed to be RH independent (Petters and Kreidenweis, 2007). Here, the $d_{\mathrm{d}}$ values used are the optically weighted median diameters, which are calculated by integrating the concentration-weighted size-dependent cross sections $\left(\sigma_{\mathrm{sca}}\left(d_{\mathrm{p}}\right)\right)$. $\mathrm{GF}(85 \%)$ values were determined by first calculating $\kappa$ based on the measured $\mathrm{GF}(\mathrm{RH})$ and then recalculating the GF at $85 \% \mathrm{RH}$.

The accuracy of this optical closure method, as well as of the initial $f(\mathrm{RH})$ measurements, was assessed by comparing the $\mathrm{GF}(85 \%)$ values determined for polydisperse distributions of $\mathrm{NaCl}$ and $\left(\mathrm{NH}_{4}\right)_{2} \mathrm{SO}_{4}$ test particles, for which $\mathrm{GF}(85 \%)$ values are known. The measured $\mathrm{GF}(85 \%)$ for $\mathrm{NaCl}$ was $2.09 \pm 0.03$ and for $\left(\mathrm{NH}_{4}\right)_{2} \mathrm{SO}_{4}$ was $1.59 \pm 0.05$, which compare very well with literature values of $\sim 2.1$ for $\mathrm{NaCl}$ (Cruz and Pandis, 2000; Laskina et al., 2015; Hansson et al., 1998) for particle sizes ranging from 100 to $300 \mathrm{~nm}$ and $\sim 1.55$ for ammonium sulfate (Laskina et al., 2015; Wise et al., 2003) for $100 \mathrm{~nm}$ particles. (The reported experimental uncertainties are $1 \sigma$ standard deviation over each measurement period.)

GF calculations for $\mathrm{PM}_{\text {all }}$ utilized a combined size distribution from the SEMS and the APS, with the merge point at $d_{\mathrm{p}}, m=1000 \mathrm{~nm}$. The APS sampled at a separate time from the CRD (see Table 1). The CRD setup also required dilution due to the $3 \mathrm{~L} \mathrm{~min}^{-1}$ required for the cyclone and a total pull of $\sim 6.3 \mathrm{~L} \mathrm{~min}^{-1}$. Therefore, a dilution correction was applied to the APS distributions to account for the different sampling scheme. Although this adjustment adds some uncertainty to the $\mathrm{PM}_{\text {all }}$ size distributions, the concentrations at larger sizes were very small and thus had minimal influence on the derived GFs. For the $\mathrm{PM}_{2.5}$ sampling periods, only SEMS distributions were used.

\section{Results}

\subsection{Size distributions and dry particle optical closure}

The daily and study average merged size distributions for each MART are shown in Fig. 2a (indoor MART) and $b$ (outdoor MART). The day-to-day variations in the size distributions were generally small. The average SSA particle number-weighted size distributions from both MARTs peaked around $d_{\mathrm{p}, \mathrm{m}}=100 \mathrm{~nm}$ and were relatively broad. The observed concentration of supermicron particles $\left(d_{\mathrm{p}, \mathrm{m}}>1000 \mathrm{~nm}\right)$ was somewhat lower than that previously reported from a MART (Stokes et al., 2013) and likely reflects greater gravitational losses of supermicron particles in the long sampling line used here (Fig. S4). Since the hygroscopicity measurements discussed in this study are based on measurements made using polydisperse distributions, it is useful to determine the effective scattering-weighted particle diameters that characterize the MART size distributions. The study-average integrated scattering for each MART was calculated from Mie theory using the observed dry particle size distributions (Fig. 2c). The $d_{\mathrm{p}, \mathrm{m}}$ at which $50 \%$ of the total scattering occurs were $570 \mathrm{~nm}$ for the outdoor MART and $530 \mathrm{~nm}$ for the indoor MART and particles with $d_{\mathrm{p}, \mathrm{m}}>1000 \mathrm{~nm}$ contributed $<10 \%$ of the total scattering in both MARTs, indicating that the derived $\mathrm{GF}(85 \%)$ values for these two experiments are most sensitive to submicron particles with $d_{\mathrm{p}, \mathrm{m}}$ values between about 400 and $800 \mathrm{~nm}$.

The extent of agreement between the observed $b_{\text {sca }}$ for dry particles and the values calculated from Mie theory using measured size distributions (Eq. 3) has been assessed (Fig. S5). The calculated $b_{\text {sca }}$ are $\sim 15 \%$ lower than the observed $b_{\text {sca }}$ for both $\mathrm{PM}_{\text {all }}$ and $\mathrm{PM}_{2.5}$, which is outside the combined uncertainty for the CRD and size distribution measurements (which is $\sim 11 \%$ from error propagation). Some of the difference may result from differential losses between or within the sizing instruments and the CRD, although this seems generally unlikely to explain the entire difference, as losses of particles in the submicron range should be small. 

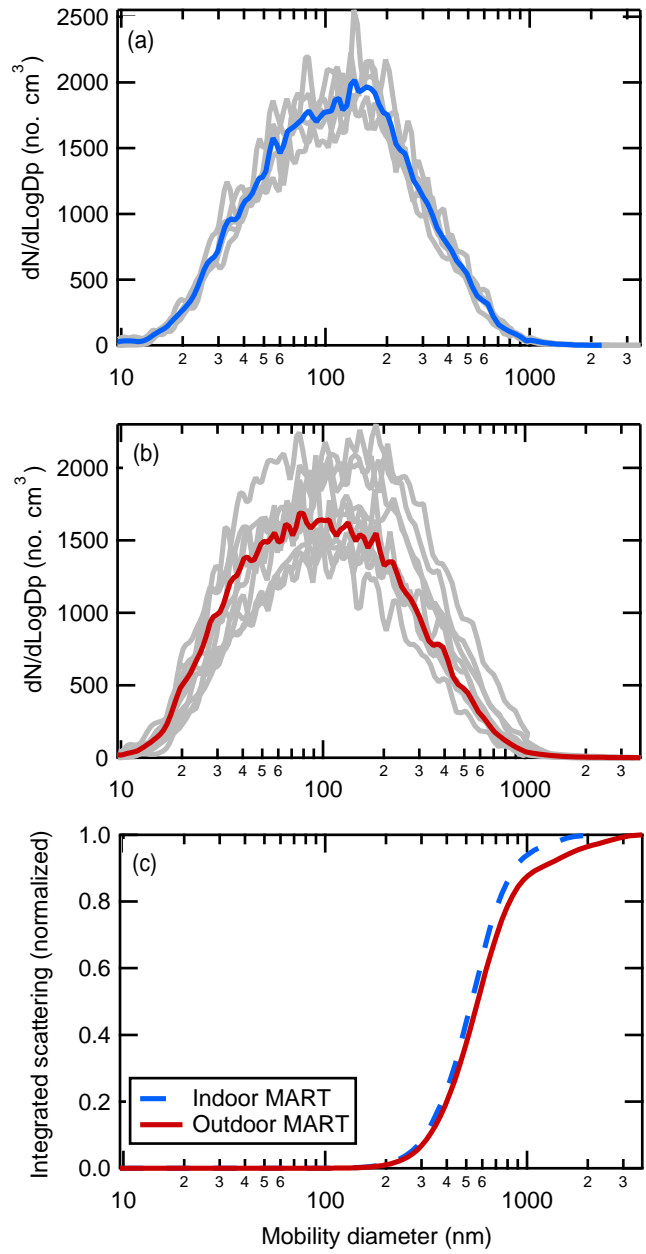

Figure 2. Single (gray) and average (red or blue) number-weighted merged size distributions for the (a) "indoor" and (b) "outdoor" MARTs averaged over the MART sampling period $(1.5 \mathrm{~h})$ and (c) normalized integrated scattering as a function of dry mobility diameter for the merged size distribution. The optically weighted median diameters are $530 \mathrm{~nm}$ for the indoor MART and $570 \mathrm{~nm}$ for the outdoor MART.

There is greater scatter in the $\mathrm{PM}_{\text {all }}$ light scattering comparison than there is from the $\mathrm{PM}_{2.5}$ comparison, which likely results both from the APS measurements being made at a different time than the CRD and SEMS measurements and the need for dilution correction. Some of the difference between the observed and calculated $b_{\text {sca }}$ may be attributable to the assumption of spherical particles in the calculations, although similar closure was obtained (within $16 \%$ ) between observed and calculated $b_{\text {sca }}$ for atomized $\mathrm{NaCl}$, suggesting that this is unlikely to explain the difference. It is possible that the diameters measured by the SEMS may have been too small. Wiedensohler et al. (2012) reported that sizing errors between instruments can be up to $10 \%$. If the measured diameters are increased by $8 \%$, then a $1: 1$ agreement between the measured and calculated extinction values is ob- tained. However, tests conducted during the study in which a second DMA was used to size-select monodisperse particles in the range $100-300 \mathrm{~nm}$ indicated agreement between the instruments to within $1 \%$. Additional tests after the study using $220 \mathrm{~nm}$ monodisperse polystyrene latex spheres demonstrated the SEMS sizing was good to better than $1 \%$, suggesting that sizing inaccuracies cannot explain the difference absent some fundamental problem with the data inversion procedure for size distributions (Lopez-Yglesias et al., 2014), which seems unlikely. Uncertainty in the assumed refractive index value for the dry particles may explain a small fraction $(<5 \%)$ of the difference. Additionally, if the dry particles had retained some water in the CRD but not the SEMS, then the observed $b_{\text {sca }}$ would be larger than the calculated value. However, the RH in the CRD dry channel is much lower than the efflorescence $\mathrm{RH}$ for $\mathrm{NaCl}$ ( $\sim 45 \%$, Biskos et al., 2006), and thus it seems unlikely that residual water would have contributed substantially to the difference. Regardless of the explicit reason for the difference in calculated and observed absolute values of $b_{\text {sca }}$, since the calculation of $f(\mathrm{RH})$ depends on the ratio between the $b_{\text {sca }}$ for wet and dry particles, such absolute differences do not strongly affect the retrieval of $\mathrm{GF}(85 \%)$ values. We have tested the sensitivity of the retrieval method to an $8 \%$ increase in the particle diameters. The retrieved GF values are increased by a marginal amount $(0.015-0.03)$ when the diameters are increased, and thus such potential sizing uncertainty does not affect the main conclusions presented here.

\subsection{Indoor MART}

The temporal variation in Chl $a$ concentrations, the derived $\mathrm{GF}(85 \%)$, and various particle composition metrics are shown in Fig. 3 for the indoor MART. As has been previously observed in microcosm experiments, the measured $\mathrm{Chl} a$ time series exhibits a distinct peak (Lee et al., 2015), which in this case occurred on 16 July at a value of $10 \mu \mathrm{g} \mathrm{L}^{-1}$. This Chl $a$ concentration is around the upper end of values observed for large phytoplankton blooms observed in the oceans, in particular near coastal regions (O'Reilly et al., 1998). After the peak the Chl $a$ concentration dropped relatively quickly to around $1.5 \mu \mathrm{g} \mathrm{L}^{-1}$ (15\% of the peak) and then eventually to $\sim 1.4 \mu \mathrm{g} \mathrm{L}^{-1}$ (14\% of the peak). The DOC concentrations varied from 240 to $350 \mu \mathrm{M} \mathrm{C}$, increasing rapidly when the $\mathrm{Chl} a$ concentration peaked and then staying relatively constant around $320 \mu \mathrm{M}$ (Fig. S6A). The peak DOC range is somewhat larger than values typically observed for blooms in the ocean, which are only $\sim 130$ $250 \mu$ M C (Kirchman et al., 1991; Norrman et al., 1995). The temporal variation in heterotrophic bacteria concentration was similar to that for DOC, and heterotrophic bacteria concentrations ranged from $\sim 1 \times 10^{6}$ to $1.2 \times 10^{7} \mathrm{~mL}^{-1}$ (Fig. S6A), which is comparable to concentrations observed in the ocean $(\mathrm{Li}, 1998)$. 

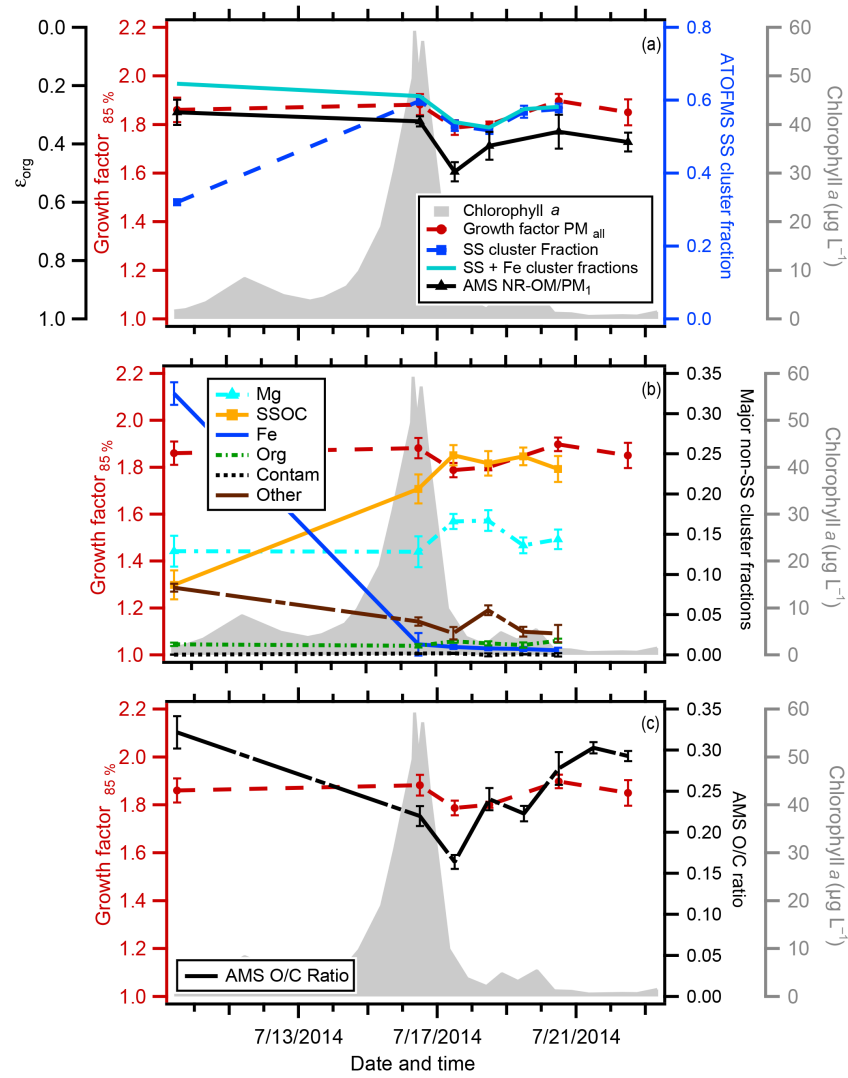

Figure 3. Time series for the indoor MART chlorophyll $a$ (gray), $\mathrm{PM}_{\text {all }} \mathrm{GF}(85 \%)$ (red circles), and (a) organic volume fraction $\left(\varepsilon_{\text {org }}\right)$ estimated from AMS non-refractory organic matter (NR$\mathrm{POM}) / \mathrm{PM}_{1}$ mass (solid black line), ATOFMS sea salt (SS) particle type fractions (blue dashed line), and ATOFMS SS + iron-type (Fe) particle type fractions; (b) dominant non-sea salt particle type fractions magnesium (Mg) type (dashed turquoise line), Fe, "other" type, and contamination (black line) and sea salt with organic carbon (SSOC) (orange line) particle type fractions; and (c) the AMS $\mathrm{O} / \mathrm{C}$ ratio (dashed black line). Note that the axis for $\varepsilon_{i}$ is reversed to facilitate comparison to $\mathrm{GF}(85 \%)$ values. The reported standard deviation for all properties is $1 \sigma$ of the individual measurements over each sampling period.

The $\mathrm{GF}(85 \%)$ values determined for the indoor MART ranged from 1.79 to 1.9 and exhibited distinct temporal variations, decreasing from $1.88 \pm 0.04$ on 16 July, just as the Chl $a$ peaked, to a minimum range of $1.79 \pm 0.03$ to $1.80 \pm 0.01$ from 17 July to 18 July when the Chl $a$ concentration dropped to $3.41 \pm 1.89 \mu \mathrm{g} \mathrm{L}^{-1}$ and then recovering back to $1.90 \pm 0.03$ on $7 / 20$ (Fig. 3a). The range of these values is $10-15 \%$ lower than the value of $\sim 2.1$ for pure (inorganic) sea salt (Ming and Russell, 2001). There is a 1-day lag between the peak in Chl $a$ and the (temporary) depression in $\mathrm{GF}(85 \%)$.

The NR-OM volume fractions of SSA varied from 0.29 to 0.50 throughout the course of the indoor MART microcosm experiment (Fig. 3). The observation of such large $\varepsilon_{\text {org }}$ values is consistent with the substantial depressions in the $\mathrm{GF}(85 \%)$ values relative to pure inorganic sea salt (2.1). The temporal variation in the $\varepsilon_{\text {org }}$ was generally similar to that of the $\mathrm{GF}(85 \%)$ values, with smaller $\mathrm{GF}(85 \%)$ values corresponding to larger $\varepsilon_{\text {org }}$ values, although the peak in $\varepsilon_{\text {org }}$ is somewhat sharper than the dip in the $\mathrm{GF}(85 \%)$. The inverse relationship between the $\mathrm{GF}(85 \%)$ and $\varepsilon_{\text {org }}$ is consistent with organic compounds being less hygroscopic than sea salt. The $\mathrm{O}: \mathrm{C}$ ratio of the NR-OM had an average value of $0.25 \pm 0.05$ $(1 \sigma)$, which is similar to the value of $0.20 \pm 0.08$ reported by Frossard et al. (2014) for primary NR-OM that was generated from the open ocean using the "sea sweep" (Bates et al., 2012). The $\mathrm{O}: \mathrm{C}$ ratio of NR-OM in the indoor MART generally increased with time, from 0.17 to 0.30 , but also exhibited a temporary decrease on 17 July, the day when the GF(85\%) and $\varepsilon_{\text {org }}$ both first dropped. Since O : C often correlates with hygroscopicity for organics (at least for multi-component mixtures), this behavior may indicate a general increase in the hygroscopicity of the NR-OM with time (Cappa et al., 2011; Massoli et al., 2010). However, since the hygroscopicity of organic aerosol with $\mathrm{O}: \mathrm{C}$ values in this range has generally been found to be small, the observed variations in $\mathrm{O}$ : C may not have a noticeable impact on the overall behavior of the $\mathrm{GF}(85 \%)$ values.

The explicit co-variation of $\varepsilon_{\text {org }}$ and the $\mathrm{GF}(85 \%)$ values is shown in Fig. 4. Assuming that volume mixing rules apply (i.e., the Zdanovskii-Stokes-Robinson (ZSR) mixing rules; Stokes and Robinson, 1966), the overall effective GF ( $\left.\mathrm{GF}_{\mathrm{obs}}\right)$ can be estimated as

$\mathrm{GF}_{\mathrm{obs}}=\left(\left(1-\varepsilon_{\text {org }}\right) \cdot \mathrm{GF}_{\text {sea salt }}{ }^{3}+\varepsilon_{\text {org }} \cdot \mathrm{GF}_{\text {org }}{ }^{3}\right)^{1 / 3}$,

where $\mathrm{GF}_{\text {org }}$ is the $\mathrm{GF}$ value for pure $\mathrm{OM}$ and $\mathrm{GF}_{\text {sea salt }}$ is the GF value expected for pure sea salt. The ZSR line connecting $\mathrm{GF}_{\text {sea salt }}(85 \%)=2.1$ and $\mathrm{GF}_{\text {org }}(85 \%)=1.0$ provides the minimum value expected for any fraction of $\mathrm{OM}$ relative to sea salt. Low $\mathrm{GF}_{\text {org }}(85 \%)$ values $(\sim 1.0)$ have been observed for fatty acids (Vesna et al., 2008), which have been found in SSA particles in the atmosphere (Mochida et al., 2002) and were observed in SSA produced in a related mesocosm experiment (Wang et al., 2015; Cochran et al., 2016). Values above this line indicate that the GF of the OM in the sampled SSA particles is, on average, greater than 1. Equation (5) was fit to the data shown in Fig. 4 to determine an average value for $\mathrm{GF}_{\text {org }}(85 \%)$ for the indoor MART. The best-fit $\mathrm{GF}_{\mathrm{org}}(85 \%)$ was $1.16 \pm 0.09$, which falls between $\mathrm{GF}_{\text {org }}=1.0$ expected for non-hygroscopic $\mathrm{OM}$, such as fatty acids, and $\mathrm{GF}_{\text {org }}$ expected for more soluble $\mathrm{OM}$, such as sugars (e.g., $\mathrm{GF}_{\mathrm{org}}(85 \%)=1.24 \pm 0.04$ has been observed for glucose; Mochida and Kawamura, 2004). (The uncertainty on $\mathrm{GF}_{\text {org }}(85 \%)$ is the fit uncertainty and does not account for uncertainties in either the CE for SSA particles or $\rho_{\mathrm{OM}}$.) This value for $\mathrm{GF}_{\text {org }}$ can be interpreted as an optically weighted average for the OM component of the SSA particles sampled here. Although the derived $\mathrm{GF}_{\text {org }}$ values are reasonable, as 


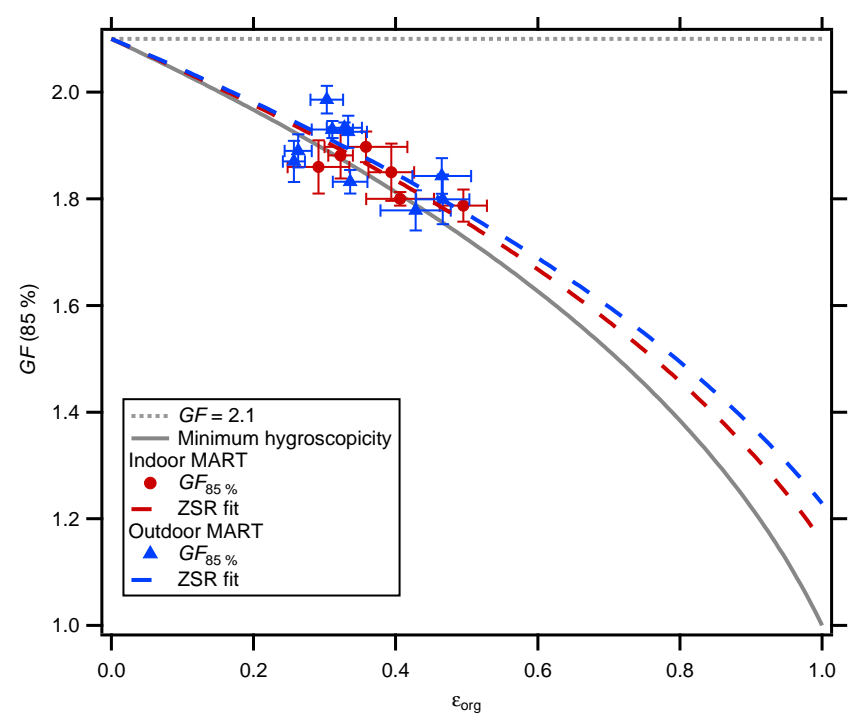

Figure 4. $\mathrm{PM}_{\mathrm{all}} \mathrm{GF}(85 \%)$ as a function of the organic volume fraction estimated from AMS non-refractory organic matter (NR$\mathrm{POM}) / \mathrm{PM}_{1}$ mass for the indoor (red circles) and the outdoor (blue triangles) MARTs. ZSR fits to the data using Eq. (5) are shown for the indoor (dashed red line) and outdoor (dashed blue line) MARTs, assuming $\mathrm{GF}_{\text {sea salt }}(85 \%)=2.1$ (dotted gray line). The overall retrieved $\mathrm{GF}_{\text {org }}(85 \%)$ values were $1.16 \pm 0.09$ and $1.23 \pm 0.10$ for the indoor and outdoor MARTs, respectively. The gray solid line connecting $\mathrm{GF}(85 \%)=2.1$ and $\mathrm{GF}_{\mathrm{org}}(85 \%)=1.0$ provides the minimum value expected for any combination of $\mathrm{GF}(85 \%)$.

the $\mathrm{CE}$ is relatively uncertain for sea spray particles (Ovadnevaite et al., 2012; Frossard et al., 2014) and the $\rho_{\mathrm{OM}}$ is also uncertain, the derived value for $\mathrm{GF}_{\text {org }}$ should be viewed as suggestive only.

One important issue to consider in assessing the quantitative nature of the derived $\mathrm{GF}_{\text {org }}(85 \%)$ value is that the mass-weighted organic fractions used to determine $\varepsilon_{\text {org }}$ do not necessarily have the same weighting with respect to particle size as the $\mathrm{GF}(85 \%)$ values do. The scattering-weighted median diameter, relevant to the $\mathrm{GF}(85 \%)$ measurements, was $d_{\mathrm{p}, \mathrm{m}}=530 \mathrm{~nm}$. The mass-weighted size distribution of $\mathrm{OM}$ can be estimated from the size distribution of a particular tracer ion in the AMS mass spectrum, specifically the ion at $m / z=43$, which is indicative of total organic mass (Fig. S7). (Interference from the large signal contribution from inorganic ions prohibited explicit determination of the total NROM size distribution, and thus only the $m / z=43$ ion is used.) The peak in the NR-OM mode occurs at $d_{\mathrm{va}} \sim 1 \mu \mathrm{m}$, which corresponds to $d_{\mathrm{p}, \mathrm{m}}=560 \mathrm{~nm}$. This is comparable to the scattering-weighted median diameter, suggesting that the temporal variations in the $\mathrm{GF}(85 \%)$ and $\varepsilon_{\text {org }}$ can be compared. However, the AMS aerodynamic lens imposes a $50 \%$ cut diameter of $\sim 1 \mu \mathrm{m}$ (Canagaratna et al., 2007) and thus the observed peak in $m / z 43$ likely occurs at a diameter that is somewhat too small compared to the actual distribution.
There was also a strong temporal correlation observed between the $\mathrm{GF}(85 \%)$ values and the number fractions of ATOFMS mass spectra categories. Specifically, the decrease in $\mathrm{GF}(85 \%)$ values after the bloom peak corresponded to a shift from particles that generated mass spectra dominated by sea salt ion markers (SS type) to particles with strong spectral signatures indicative of organic or biological influence (SSOC and Mg type). (The measurements made just after nutrient addition on 9 July are a notable exception, discussed below.) The inverse relationship between the $\operatorname{GF}(85 \%)$ and the SS-type particle spectra is consistent with the inverse relationship between the $\mathrm{GF}(85 \%)$ and $\varepsilon_{\text {org }}$, providing additional confidence that the temporal variations in $\mathrm{GF}(85 \%)$ are driven by variations in particle composition. The SSOC mass spectral type is identified in large part by the presence of carbon-containing peaks $\left(\mathrm{CN}^{-}\right.$and $\left.\mathrm{CNO}^{-}\right)$and $\mathrm{K}^{+}$ and $\mathrm{Ca}^{+}$in the mass spectrum (see Fig. S2). The Mg-type spectra are characterized by their large $\mathrm{Mg}^{+}$peak, which has been previously attributed to the presence of biological material (e.g., bacteria) (Guasco et al., 2013; Prather et al., 2013), as well as by smaller $\mathrm{Ca}^{+}$and $\mathrm{K}^{+}$peaks (Fig. S2). Both the SSOC and $\mathrm{Mg}$ spectral types are depleted in peaks corresponding to $\mathrm{Na}$ or $\mathrm{NaCl}$. It is important to note, however, that dried SSA particles sampled by the ATOFMS can be spatially chemically heterogeneous, with shells depleted in $\mathrm{Na}$ and rich in $\mathrm{Mg}, \mathrm{K}$, and $\mathrm{Ca}$ (Ault et al., 2013). Thus, some fraction of the particles identified as having $\mathrm{Mg}$ - or SSOC-type spectra may be partially explained by the incomplete ionization of sea salt particles (Sultana et al., 2016). However, variations in the thickness of this Na-depleted shell likely reflect variations in the total particle organic content. Therefore, increases in the fraction of SSOC- or Mg-type mass spectra generated suggest a net increase in SSA particle organic content. On 9 July a substantial fraction of particles containing large $\mathrm{Fe}^{+}$peaks were observed; on all other days the Fe spectral-type particle fraction was negligible. The Fe spectral-type particles may have had an influence on the observed $\mathrm{GF}(85 \%)$ values when present with high relative abundance. However, their large fraction on 9 July is a result of nutrient addition and not biological changes in the seawater.

\subsection{Outdoor MART}

The temporal variation in $\mathrm{Chl} a$ concentrations, the derived $\mathrm{GF}(85 \%)$ values and various particle composition metrics are shown in Fig. 5 for the outdoor MART. Like the indoor MART, the Chl $a$ concentrations exhibited a characteristic rise and fall for the microcosm experiment. However, the maximum Chl $a$ concentration was $51 \mu \mathrm{g} \mathrm{L}{ }^{-1}$, which is 5 times higher than the indoor MART and likely due to greater PAR in the outdoor MART. Such high Chl $a$ concentrations are well above those typically observed in the ocean. However, the Chl $a$ concentration rapidly declined to $6 \mu \mathrm{g} \mathrm{L}-1$ 2 days after the peak and then continued to decrease over the 


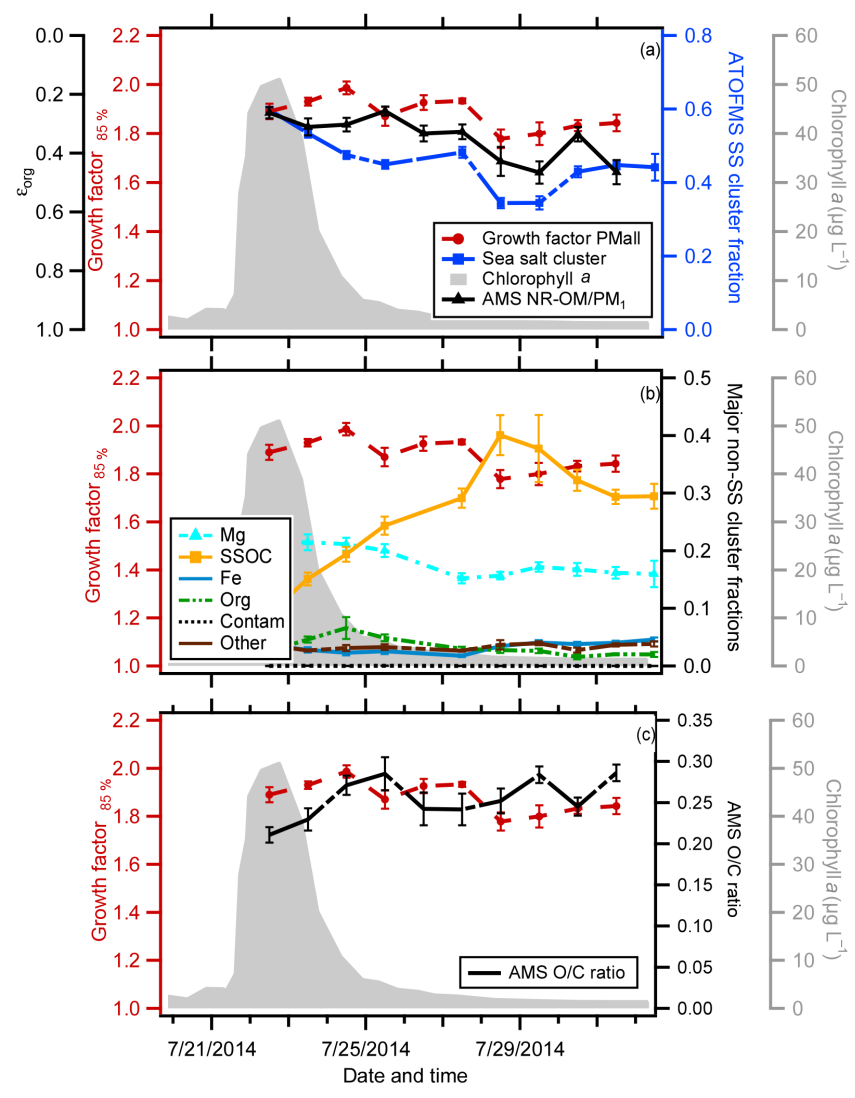

Figure 5. Same as Fig. 3 above but for the outdoor MART.

next week to $<1.5 \mu \mathrm{g} \mathrm{L}{ }^{-1}$. Both DOC and heterotrophic bacteria concentrations increased as the bloom progressed until they stabilized around the point when Chl $a$ concentrations had returned approximately to their pre-bloom levels, with DOC concentrations ranging from 200 to $300 \mu \mathrm{M} \mathrm{C}$ and heterotrophic bacteria concentrations from $1 \times 10^{6}$ to a peak of $1.7 \times 10^{7} \mathrm{~mL}^{-1}$ (Fig. S6B).

The $\mathrm{GF}(85 \%)$ values ranged from a maximum of $1.99 \pm 0.03$ to a minimum of $1.78 \pm 0.04$, again lower than what would be expected for pure sea salt (by $5-15 \%$ ). Unfortunately, no pre-bloom measurements were possible for this experiment, with the first particle measurements made for all instruments when the $\mathrm{Chl} a$ concentration was peaking. The smallest GF $(85 \%)$ values were observed towards the end of the microcosm, when the $\mathrm{Chl} a$ concentrations were at their lowest point $\left(<1.5 \mu \mathrm{g} \mathrm{L}^{-1}\right)$. The $\mathrm{GF}(85 \%)$ values exhibited two sequential decreases after the $\mathrm{Chl} a$ peak, the first after 3 days and the second after 6 days. The range of GF( $85 \%)$ values for the SSA particles from the outdoor MART was similar to that for the indoor MART.

The observed $\varepsilon_{\text {org }}$ values for the SSA particles were similarly comparable to the indoor MART $(0.26$ to 0.46$)$. In general, decreases in $\mathrm{GF}(85 \%)$ values corresponded to increases in $\varepsilon_{\text {org }}$ values, with the exception of the measurements on $7 / 30$ (Fig. 5c). Following the peak in $\mathrm{Chl} a$, the $\varepsilon_{\text {org }}$ values increase gradually over a few days, then stabilize, and finally exhibit an additional increase 6 days after the bloom peak (Fig. 5a). The temporal variations in $\varepsilon_{\text {org }}$ tracks neither the Chl $a$ nor DOC concentrations. This suggests that, perhaps, biological processing and its impact on the composition of organics in the sea water, more so than absolute organic concentrations, is important for determining the abundance of organic matter transferred into SSA particles (Rinaldi et al., 2013; Lee et al., 2015; Quinn et al., 2014). However, further experiments will be needed to confirm this hypothesis

Values of $\mathrm{GF}_{\text {org }}(85 \%)$ have again been estimated using the ZSR relationship (Eq. 5) and the observed GF(85\%) and $\varepsilon_{\text {org }}$. Assuming $\mathrm{GF}_{\text {sea salt }}(85 \%)=2.1$, the derived $\mathrm{GF}_{\text {org }}(85 \%)=1.23 \pm 0.10$ (Fig. 4). This $\mathrm{GF}_{\text {org }}(85 \%)$ for the outdoor MART is comparable to that obtained from the indoor MART, suggesting that the OM generated from the outdoor MART has similar hygroscopicity as the OM sampled from the indoor MART.

As with the indoor MART, there was a reasonable temporal correlation between the $\mathrm{GF}(85 \%)$ values and the number concentration of SS spectral-type particles from the ATOFMS. The two most abundant non-SS particle mass spectra types were SSOC type and Mg type, with all other types contributing negligibly. This is again an indication that the temporal variation in the $\mathrm{GF}(85 \%)$ values corresponds to an evolution of the composition of the SSA particle population and is consistent with the variation in $\varepsilon_{\text {org }}$.

\section{Implications and conclusions}

The two MART microcosm studies provide two case studies relating variations in the optically weighted $\mathrm{GF}(85 \%)$ values and SSA particle composition for predominately submicrometer SSA particles. For both microcosms, clear depression of the $\mathrm{GF}(85 \%)$ values, relative to that for pure sea salt, occurred following the peak in $\mathrm{Chl} a$ concentrations and upon the death of both phytoplankton blooms, but with differing time lags between peak Chl $a$ and the minimum GF( $85 \%)$ between the experiments. This depression in $\mathrm{GF}(85 \%)$ values is consistent with large $\varepsilon_{\text {org }}(0.25-0.50)$ values estimated using the NR-OM/PM $\mathrm{PM}_{1}$. The similar temporal variations in $\mathrm{GF}(85 \%)$ and $\varepsilon_{\text {org }}$, as well as with the ATOFMS particle mass spectra types, demonstrate a clear link between SSA hygroscopicity and composition. For a given microcosm experiment, the estimated hygroscopicity of OM components is similar, with $\mathrm{GF}(85 \%)=1.16$ for the indoor MART and 1.23 for the outdoor MART.

The observations here demonstrate that the climate impacts of marine-derived organic compounds can go beyond their demonstrated ability to influence cloud condensation nuclei efficacy (Quinn et al., 2014; Collins et al., 2013), additionally affecting the efficiency with which SSA particles scatter solar radiation. This was previously suggested by the ambient measurements of Vaishya et al. (2013), who ob- 
served substantial differences in $\mathrm{GF}(90 \%)$ and $f(\mathrm{RH})$ values for submicron particles with very different $\varepsilon_{\text {org }}$ fractions in what were identified as clean marine air masses. (Their GF(90\%) values were measured using a hygroscopic tandem DMA for size-selected particles with $35 \mathrm{~nm}$ $\leq d_{\mathrm{p}, \mathrm{m}} \leq 165 \mathrm{~nm}$. Their $f(\mathrm{RH})$ values were measured for $\mathrm{PM}_{1}$.) They observed that increases in $\varepsilon_{\text {org }}$ had no effect on the $\mathrm{GF}(90 \%)$ until a threshold $\varepsilon_{\text {org }}$ was reached, specifically $\varepsilon_{\text {org }}>\sim 55 \%$. Below this value, they measured $\mathrm{GF}(90 \%)$ value of $\sim 2.3$, which is the expected value for pure sea salt at $\mathrm{RH}=90 \%$. Above this value, the observed a rapid fall off in $\mathrm{GF}(90 \%)$ to a plateau at 1.22 . This reported behavior differs from that observed for nascent SSA particles sampled in the current study. Here, substantial depressions in $\mathrm{GF}(85 \%)$ (and $f(\mathrm{RH})$ ) relative to inorganic sea salt were observed when the $\varepsilon_{\text {org }}$ was only $\sim 25 \%$, and a co-variation between $\mathrm{GF}(85 \%)$ and $\varepsilon_{\text {org }}$ (and the ATOFMS SS spectraltype fraction) was observed. One plausible reason for this difference is that nascent (freshly emitted) SSA particles are measured here whereas Vaishya et al. (2013) measured ambient particles that could be subject to photochemical processing. Secondary organic aerosol formed from gases, such as monoterpenes and isoprene, emitted from the ocean (Shaw et al., 2010) could have contributed to the NR-OM, although Vaishya et al. (2013) argue that this influence was negligible based on the literature. Emission rates of such species from the ocean and their relationship with oceanic processes are not well established. Although Vaishya et al. (2013) attempted to remove the influence of secondary organics in their analysis (as well as the influence of non-sea salt sulfate), it is possible that their analysis was complicated by the impacts of atmospheric processing. Another key difference is that relationship between the $\mathrm{GF}(85 \%)$ values and $\varepsilon_{\text {org }}$ observed in the current study is consistent with ZSR behavior, while Vaishya et al. (2013) reported "bistable" behavior of the $\mathrm{GF}(90 \%)$ values as a function $\varepsilon_{\text {org }}$ (i.e., the flat behavior at $\varepsilon_{\mathrm{org}}<55 \%$ and the steep fall off above). The physical basis of this bistable behavior, and the functional form implied by their measurements, is not easily explained. Finally, the $\mathrm{GF}(90 \%)$ measurements by Vaishya et al. were made for particles with $d_{\mathrm{p}, \mathrm{m}}<165 \mathrm{~nm}$, while the composition was characterized with an HR-AMS. It is possible that size mismatch between these measurements influenced their analysis. Massweighted size distributions were not shown by Vaishya et al. (2013), but Frossard et al. showed mass-weighted size distributions for ambient particles sampled in the remote marine boundary layer that suggest that much of the organic mass is contained in particles $>165 \mathrm{~nm}$. Our results clearly indicate that compositional changes to nascent SSA particles, driven by variation in physical and biochemical processes in seawater, can impact the influence of water uptake on scattering by submicron SSA even when $\varepsilon_{\text {org }}<55 \%$. The comparison with the Vaishya et al. (2013) measurements suggests that this initial state can be further modified through atmospheric processing.

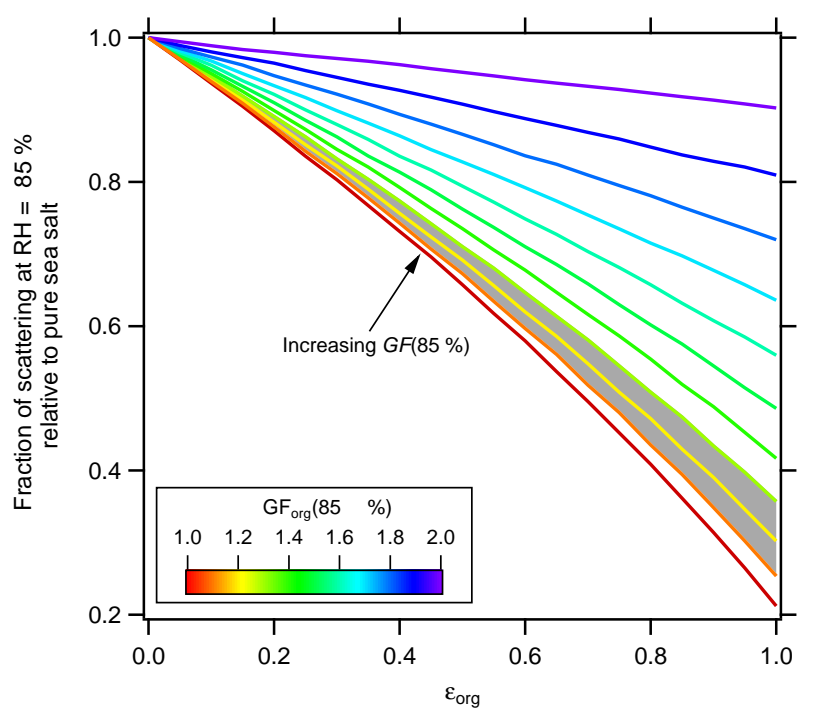

Figure 6. Calculated fraction of scattering relative to pure sea salt particles at $85 \% \mathrm{RH}$ as a function of $\varepsilon_{\mathrm{org}}$, assuming the OM component of the SSA particles have the same constant hygroscopicity and a refractive index of 1.55 and the SSA particles follow the ZSR mixing rules. The different curves are colored according to the assumed $\mathrm{GF}_{\mathrm{org}}(85 \%)$ value, ranging from 1.0 to 2.0 , given $\mathrm{GF}_{\text {sea salt }}(85 \%)=2.1$. The gray band shows the range of $\mathrm{GF}_{\text {org }}$ values indicated by the current measurements.

The implications of these results are explored here through calculations of the net decrease (relative to pure sea salt) in the average per particle scattering that would theoretically result from increasing amounts of OM in SSA particles, assuming that the SSA particles follow the ZSR mixing rules (see Fig. 6). This has been done for different assumed $\mathrm{GF}(85 \%)_{\text {org }}$ values as a function of $\varepsilon_{\text {org }}$ using the average size distribution for the outdoor MART shown in Fig. 2b. Given the particle size distributions measured here, this assessment pertains to submicron SSA, not the entire SSA particle size distribution observed over the ocean (which includes contributions from supermicron particles; Kleefeld et al., 2002). The range of $\varepsilon_{\text {org }}$ and $\mathrm{GF}_{\text {org }}(85 \%)$ values determined here (about $0.25-0.50$ and $1.16-1.23$, respectively) correspond to decreases in scattering of about 15 to $30 \%$. Thus, climate models that assume SSA particles behave like pure sea salt or $\mathrm{NaCl}$ (Stier et al., 2005; Schmidt et al., 2006) may over-predict SSA particle scattering, depending upon the exact RH fields in the model. However, the range of $\varepsilon_{\text {org }}$ observed here, $\sim 0.25$ to 0.50 , may be larger than is typical in the ambient marine atmosphere, given that the MART bloom experiments are more representative of regions of the ocean with high biological activity. For example, O'Dowd et al. (2004) observed mass fractions of $\sim 0.40$ organic matter for SSA particles with aerodynamic diameters between 0.5 and $1 \mu \mathrm{m}$ during periods with high biological productivity but $<5 \%$ for periods with low productivity. Regardless, the results presented here suggest that OM in SSA particles may 
have a non-negligible, yet variable, impact on the light scattering by SSA particles in the ambient atmosphere (Fig. S8). Most likely, the simulated cooling effect of SSA particles due to aerosol-radiation interactions (i.e., the "direct effect") would be decreased relative to the assumption that all SSA behaves as sea salt. Recent climate modeling studies (Partanen et al., 2014; O'Dowd et al., 2008) have attempted to account for variability in OM fractions of SSA particles by parameterizing OM fraction as a function of Chl $a$. However, relating the OM fraction of SSA particles to simple ocean biological metrics like Chl $a$ still remains challenging, as these metrics are often insufficient predictors for SSA particle composition (Quinn et al., 2014; Wang et al., 2015), and the measurements reported here indicate a clear lag between the peak in Chl $a$ and the minimum in the $\mathrm{GF}(85 \%)$ values. Quantitative understanding of the climate impacts of SSA particles will require further understanding of the timing and relationships between ocean biogeochemistry and SSA properties.

\section{Information about the Supplement}

The Supplement consists of six figures that provide additional support of the conclusions presented in the paper.

\section{The Supplement related to this article is available online at doi:10.5194/acp-16-9003-2016-supplement.}

\begin{abstract}
Acknowledgements. This study was funded by the Center for Aerosol Impacts on Climate and Environment (CAICE), an NSF Center for Chemical Innovation (CHE-1305427). The authors thank all IMPACTS participants and the SIO hydraulics facility staff. SDF and CDC additionally thank the students in ECI $247 \mathrm{~L}$ during spring quarter 2015 at UC Davis, who validated the SEMS sizing.
\end{abstract}

Edited by: D. Knopf

Reviewed by: two anonymous referees

\section{References}

Ault, A. P., Guasco, T. L., Ryder, O. S., Baltrusaitis, J., CuadraRodriguez, L. A., Collins, D. B., Ruppel, M. J., Bertram, T. H., Prather, K. A., and Grassian, V. H.: Inside versus outside: Ion redistribution in nitric acid reacted sea spray aerosol particles as determined by single particle analysis, J. Am. Chem. Soc., 135, 14528-14531, doi:10.1021/ja407117x, 2013.

Bates, T., Quinn, P., Frossard, A., Russell, L., Hakala, J., Petäjä, T., Kulmala, M., Covert, D., Cappa, C., and Li, S. M.: Measurements of ocean derived aerosol off the coast of california, J. Geophys. Res.-Atmos., 117, D00V15, doi:10.1029/2012JD017588, 2012.
Biskos, G., Malinowski, A., Russell, L., Buseck, P., and Martin, S.: Nanosize effect on the deliquescence and the efflorescence of sodium chloride particles, Aerosol Sci. Tech., 40, 97-106, doi:10.1080/02786820500484396, 2006.

Bouvet, M., Hoepffner, N., and Dowell, M. D.: Parameterization of a spectral solar irradiance model for the global ocean using multiple satellite sensors, J. Geophys. Res.-Oceans, 107, 8-1-818, doi:10.1029/2001JC001126, 2002.

Canagaratna, M. R., Jayne, J. T., Jimenez, J. L., Allan, J. D., Alfarra, M. R., Zhang, Q., Onasch, T. B., Drewnick, F., Coe, H., Middlebrook, A., Delia, A., Williams, L. R., Trimborn, A. M., Northway, M. J., DeCarlo, P. F., Kolb, C. E., Davidovits, P., and Worsnop, D. R.: Chemical and microphysical characterization of ambient aerosols with the aerodyne aerosol mass spectrometer, Mass Spectrom. Rev., 26, 185-222, doi:10.1002/mas.20115, 2007.

Cappa, C. D., Che, D. L., Kessler, S. H., Kroll, J. H., and Wilson, K. R.: Variations in organic aerosol optical and hygroscopic properties upon heterogeneous oh oxidation, J. Geophys. Res.-Atmos., 116, D15204, doi:10.1029/2011JD015918, 2011.

Cappa, C. D., Onasch, T. B., Massoli, P., Worsnop, D., Bates, T. S., Cross, E., Davidovits, P., Hakala, J., Hayden, K., Jobson, B T., Kolesar, K. R., Lack, D. A., Lerner, B., Li, S. M., Mellon, D., Nuaanman, I., Olfert, J., Petaja, T., Quinn, P. K., Song, C., Subramanian, R., Williams, E. J., and Zaveri, R. A.: Radiative absorption enhancements due to the mixing state of atmospheric black carbon, Science, 337, 1078-1081, doi:10.1126/science.1223447, 2012.

Carslaw, K., Lee, L., Reddington, C., Pringle, K., Rap, A., Forster, P., Mann, G., Spracklen, D., Woodhouse, M., and Regayre, L.: Large contribution of natural aerosols to uncertainty in indirect forcing, Nature, 503, 67-71, doi:10.1038/nature12674, 2013.

Cochran, R., Laskina, O., Jayarathne, T., Laskin, A., Laskin, J., Lin, P., Sultana, C. M., Moore, K. A., Cappa, C., Bertram, T., Prather, K. A., and Grassian, V. H.: Analysis of organic anionic surfactants in fine (pm2.5) and coarse (pm10) fractions of freshly emitted sea spray aerosol, Environ. Sci. Technol., 50, 2477-2486, doi:10.1021/acs.est.5b04053, 2016.

Collins, D. B., Ault, A. P., Moffet, R. C., Ruppel, M. J., CuadraRodriguez, L. A., Guasco, T. L., Corrigan, C. E., Pedler, B. E., Azam, F., and Aluwihare, L. I.: Impact of marine biogeochemistry on the chemical mixing state and cloud forming ability of nascent sea spray aerosol, J. Geophys. Res.-Atmos., 118, 85538565, doi:10.1002/jgrd.50598, 2013.

Cruz, C. N. and Pandis, S. N.: Deliquescence and hygroscopic growth of mixed inorganic-organic atmospheric aerosol, Environ. Sci. Technol., 34, 4313-4319, doi:10.1021/es9907109, 2000.

Dusek, U., Frank, G., Hildebrandt, L., Curtius, J., Schneider, J., Walter, S., Chand, D., Drewnick, F., Hings, S., and Jung, D.: Size matters more than chemistry for cloudnucleating ability of aerosol particles, Science, 312, 1375-1378, doi:10.1126/science.1125261, 2006.

Facchini, M. C., Rinaldi, M., Decesari, S., Carbone, C., Finessi, E., Mircea, M., Fuzzi, S., Ceburnis, D., Flanagan, R., and Nilsson, E. D.: Primary submicron marine aerosol dominated by insoluble organic colloids and aggregates, Geophys. Res. Lett., 35, 17814, doi:10.1029/2008GL034210, 2008. 
Farmer, D. K., Cappa, C. D., and Kreidenweis, S. M.: Atmospheric processes and their controlling influence on cloud condensation nuclei activity, Chem. Rev., 115, 4199-4217, doi:10.1021/cr5006292, 2015.

Frossard, A. A., Russell, L. M., Massoli, P., Bates, T. S., and Quinn, P. K.: Side-by-side comparison of four techniques explains the apparent differences in the organic composition of generated and ambient marine aerosol particles, Aerosol Sci. Tech., 48, v-x, doi:10.1080/02786826.2013.879979, 2014.

Fuentes, E., Coe, H., Green, D., and McFiggans, G.: On the impacts of phytoplankton-derived organic matter on the properties of the primary marine aerosol - Part 2: Composition, hygroscopicity and cloud condensation activity, Atmos. Chem. Phys., 11, 25852602, doi:10.5194/acp-11-2585-2011, 2011.

Gard, E. E., Kleeman, M. J., Gross, D. S., Hughes, L. S., Allen, J. O., Morrical, B. D., Fergenson, D. P., Dienes, T., Galli, M. E., Johnson, R. J., Cass, G. R., and Prather, K. A.: Direct observation of heterogeneous chemistry in the atmosphere, Science, 279, 1184-1187, doi:10.1126/science.279.5354.1184, 1998.

Guasco, T. L., Cuadra-Rodriguez, L. A., Pedler, B. E., Ault, A. P., Collins, D. B., Zhao, D., Kim, M. J., Ruppel, M. J., Wilson, S. C., and Pomeroy, R. S.: Transition metal associations with primary biological particles in sea spray aerosol generated in a wave channel, Environ. Sci. Technol., 48, 1324-1333, doi:10.1021/es403203d, 2013.

Hansson, H.-C., Rood, M., Koloutsou-Vakakis, S., Hämeri, K., Orsini, D., and Wiedensohler, A.: Nacl aerosol particle hygroscopicity dependence on mixing with organic compounds, J. Atmos. Chem., 31, 321-346, doi:10.1023/A:1006174514022, 1998.

Haywood, J., Ramaswamy, V., and Soden, B.: Tropospheric aerosol climate forcing in clear-sky satellite observations over the oceans, Science, 283, 1299-1303, doi:10.1126/science.283.5406.1299, 1999.

Hegg, D. A., Covert, D. S., and Jonsson, H. H.: Measurements of size-resolved hygroscopicity in the California coastal zone, Atmos. Chem. Phys., 8, 7193-7203, doi:10.5194/acp-8-7193-2008, 2008.

IPCC: Climate change 2013: The physical science basis. Contribution of working group $i$ to the fifth assessment report of the intergovernmental panel on climate change, Cambridge University Press, Cambridge, United Kingdom and New York, NY, USA, 1535 pp., 2013.

Keene, W. C., Maring, H., Maben, J. R., Kieber, D. J., Pszenny, A. A., Dahl, E. E., Izaguirre, M. A., Davis, A. J., Long, M. S., and Zhou, X.: Chemical and physical characteristics of nascent aerosols produced by bursting bubbles at a model air-sea interface, J. Geophys. Res.-Atmos., 112, D21202, doi:10.1029/2007JD008464, 2007.

Kirchman, D. L., Suzuki, Y., Garside, C., and Ducklow, H. W.: High turnover rates of dissolved organic carbon during a spring phytoplankton bloom, Nature, 352, 612-614, doi:10.1038/352612a0, 1991.

Kleefeld, C., O’Dowd, C. D., O'Reilly, S., Jennings, S. G., Aalto, P., Becker, E., Kunz, G., and de Leeuw, G.: Relative contribution of submicron and supermicron particles to aerosol light scattering in the marine boundary layer, J. Geophys. Res.-Atmos., 107, PAR 8-1-PAR 8-13, doi:10.1029/2000JD000262, 2002.
Kulkarni, P., Baron, P. A., and Willeke, K.: Aerosol measurement: Principles, techniques, and applications, John Wiley \& Sons, ISBN-13: 9780470387412, 2011.

Langridge, J. M., Richardson, M. S., Lack, D., Law, D., and Murphy, D. M.: Aircraft instrument for comprehensive characterization of aerosol optical properties, part i: Wavelength-dependent optical extinction and its relative humidity dependence measured using cavity ringdown spectroscopy, Aerosol Sci. Tech., 45, 1305-1318, doi:10.1080/02786826.2011.592745, 2011.

Laskina, O., Morris, H. S., Grandquist, J. R., Qin, Z., Stone, E. A., Tivanski, A. V., and Grassian, V. H.: Size matters in the water uptake and hygroscopic growth of atmospherically relevant multicomponent aerosol particles, The Journal of Physical Chemistry A, 119, 4489-4497, doi:10.1021/jp510268p, 2015.

Lawler, M. J., Whitehead, J., O’Dowd, C., Monahan, C., McFiggans, G., and Smith, J. N.: Composition of 15-85 nm particles in marine air, Atmos. Chem. Phys., 14, 11557-11569, doi:10.5194/acp-14-11557-2014, 2014.

Lee, C., Sultana, C. M., Collins, D. B., Santander, M. V., Axson, J. L., Malfatti, F., Cornwell, G. C., Grandquist, J. R., Deane, G. B., Stokes, M. D., Azam, F., Grassian, V. H., and Prather, K. A.: Advancing model systems for fundamental laboratory studies of sea spray aerosol using the microbial loop, The Journal of Physical Chemistry A, 119, 8860-8870, doi:10.1021/acs.jpca.5b03488, 2015.

Lewis, E. R. and Schwartz, S. E.: Sea salt aerosol production: Mechanisms, methods, measurements, and models-a critical review, American Geophysical Union, Washington, DC, ISBN-10: 087590-417-3, 2004.

Li, W. K.: Annual average abundance of heterotrophic bacteria and synechococcus in surface ocean waters, Limnol. Oceanogr., 43, 1746-1753, doi:10.4319/lo.1998.43.7.1746, 1998.

Lopez-Yglesias, X. F., Yeung, M. C., Dey, S. E., Brechtel, F. J., and Chan, C. K.: Performance evaluation of the brechtel mfg. Humidified tandem differential mobility analyzer (bmi htdma) for studying hygroscopic properties of aerosol particles, Aerosol Sci. Tech., 48, 969-980, doi:10.1080/02786826.2014.952366, 2014.

Massoli, P., Lambe, A., Ahern, A., Williams, L., Ehn, M., Mikkilä, J., Canagaratna, M., Brune, W., Onasch, T., and Jayne, J.: Relationship between aerosol oxidation level and hygroscopic properties of laboratory generated secondary organic aerosol (soa) particles, Geophys. Res. Lett., 37, L24801, doi:10.1029/2010GL045258, 2010.

Ming, Y. and Russell, L. M.: Predicted hygroscopic growth of sea salt aerosol, J. Geophys. Res.-Atmos., 106, 28259-28274, doi:10.1029/2001JD000454, 2001.

Mochida, M. and Kawamura, K.: Hygroscopic properties of levoglucosan and related organic compounds characteristic to biomass burning aerosol particles, J. Geophys. Res.-Atmos., 109, D21202, doi:10.1029/2004jd004962, 2004.

Mochida, M., Kitamori, Y., Kawamura, K., Nojiri, Y., and Suzuki, $\mathrm{K}$.: Fatty acids in the marine atmosphere: Factors governing their concentrations and evaluation of organic films on sea-salt particles, J. Geophys. Res.-Atmos., 107, AAC 1-1-AAC 1-10, 2002.

Modini, R. L., Harris, B., and Ristovski, Z. D.: The organic fraction of bubble-generated, accumulation mode Sea Spray Aerosol (SSA), Atmos. Chem. Phys., 10, 2867-2877, doi:10.5194/acp10-2867-2010, 2010. 
Norrman, B., Zwelfel, U. L., Hopkinson, C. S., and Brian, F.: Production and utilization of dissolved organic carbon during an experimental diatom bloom, Limnol. Oceanogr., 40, 898-907, doi:10.4319/lo.1995.40.5.0898, 1995.

O’Dowd, C. D., Facchini, M. C., Cavalli, F., Ceburnis, D., Mircea, M., Decesari, S., Fuzzi, S., Yoon, Y. J., and Putaud, J.-P.: Biogenically driven organic contribution to marine aerosol, Nature, 431, 676-680, doi:10.1038/nature02959, 2004.

O’Dowd, C. D., Langmann, B., Varghese, S., Scannell, C., Ceburnis, D., and Facchini, M. C.: A combined organic-inorganic sea-spray source function, Geophys. Res. Lett., 35, L01801, doi:10.1029/2007GL030331, 2008.

O'Reilly, J. E., Maritorena, S., Mitchell, B. G., Siegel, D. A., Carder, K. L., Garver, S. A., Kahru, M., and McClain, C.: Ocean color chlorophyll algorithms for seawifs, J. Geophys. Res.-Oceans, 103, 24937-24953, doi:10.1029/98JC02160, 1998.

Ovadnevaite, J., Ceburnis, D., Martucci, G., Bialek, J., Monahan, C., Rinaldi, M., Facchini, M. C., Berresheim, H., Worsnop, D. R., and O'Dowd, C.: Primary marine organic aerosol: A dichotomy of low hygroscopicity and high ccn activity, Geophys. Res. Lett., 38, L21806, doi:10.1029/2011GL048869, 2011.

Ovadnevaite, J., Ceburnis, D., Canagaratna, M., Berresheim, H., Bialek, J., Martucci, G., Worsnop, D. R., and O’Dowd, C.: On the effect of wind speed on submicron sea salt mass concentrations and source fluxes, J. Geophys. Res.-Atmos., 117, D16201,, doi:10.1029/2011jd017379, 2012.

Park, J. Y., Lim, S., and Park, K.: Mixing state of submicrometer sea spray particles enriched by insoluble species in bubblebursting experiments, J. Atmos. Ocean. Tech., 31, 93-104, doi:10.1175/JTECH-D-13-00086.1, 2014.

Partanen, A.-I., Dunne, E. M., Bergman, T., Laakso, A., Kokkola, H., Ovadnevaite, J., Sogacheva, L., Baisnée, D., Sciare, J., Manders, A., O’Dowd, C., de Leeuw, G., and Korhonen, H.: Global modelling of direct and indirect effects of sea spray aerosol using a source function encapsulating wave state, Atmos. Chem. Phys., 14, 11731-11752, doi:10.5194/acp-14-11731-2014, 2014.

Petters, M. D. and Kreidenweis, S. M.: A single parameter representation of hygroscopic growth and cloud condensation nucleus activity, Atmos. Chem. Phys., 7, 1961-1971, doi:10.5194/acp-71961-2007, 2007.

Pilinis, C., Pandis, S. N., and Seinfeld, J. H.: Sensitivity of direct climate forcing by atmospheric aerosols to aerosol size and composition, J. Geophys. Res.-Atmos., 100, 18739-18754, doi:10.1029/95JD02119, 1995.

Pomeroy, L. R., Williams, P. J. L. B., Azam, F., and Hobbie, J. E.: The microbial loop, Oceanography, 20, 28-33, doi:10.5670/oceanog.2007.45, 2007.

Prather, K. A., Bertram, T. H., Grassian, V. H., Deane, G. B., Stokes, M. D., DeMott, P. J., Aluwihare, L. I., Palenik, B. P., Azam, F., and Seinfeld, J. H.: Bringing the ocean into the laboratory to probe the chemical complexity of sea spray aerosol, P. Natl. Acad. Sci. USA, 110, 7550-7555, doi:10.1073/pnas.1300262110, 2013.

Pratt, K. A., DeMott, P. J., French, J. R., Wang, Z., Westphal, D. L., Heymsfield, A. J., Twohy, C. H., Prenni, A. J., and Prather, K. A.: In situ detection of biological particles in cloud ice-crystals, Nat. Geosci., 2, 397-400, doi:10.1038/ngeo521, 2009.

Quinn, P. K., Bates, T. S., Schulz, K. S., Coffman, D. J., Frossard, A. A., Russell, L. M., Keene, W. C., and Kieber, D. J.: Con- tribution of sea surface carbon pool to organic matter enrichment in sea spray aerosol, Nature Geosci, 7, 228-232, doi:10.1038/ngeo2092, 2014.

Quinn, P. K., Collins, D. B., Grassian, V. H., Prather, K. A., and Bates, T. S.: Chemistry and related properties of freshly emitted sea spray aerosol, Chem. Rev., 115, 4383-4399, doi:10.1021/cr500713g, 2015.

Rinaldi, M., Fuzzi, S., Decesari, S., Marullo, S., Santoleri, R., Provenzale, A., Hardenberg, J., Ceburnis, D., Vaishya, A., and O'Dowd, C. D.: Is chlorophyll $a$ the best surrogate for organic matter enrichment in submicron primary marine aerosol?, J. Geophys. Res.-Atmos., 118, 4964-4973, doi:10.1002/jgrd.50417, 2013.

Saxena, P., Hildemann, L. M., McMurry, P. H., and Seinfeld, J. H.: Organics alter hygroscopic behavior of atmospheric particles, J. Geophys. Res.-Atmos., 100, 18755-18770, doi:10.1029/95JD01835, 1995.

Schmidt, G. A., Ruedy, R., Hansen, J. E., Aleinov, I., Bell, N., Bauer, M., Bauer, S., Cairns, B., Canuto, V., and Cheng, Y.: Present-day atmospheric simulations using giss modele: Comparison to in situ, satellite, and reanalysis data, J. Climate, 19, 153-192, 2006.

Sellegri, K., Villani, P., Picard, D., Dupuy, R., O’Dowd, C., and Laj, P.: Role of the volatile fraction of submicron marine aerosol on its hygroscopic properties, Atmos. Res., 90, 272-277, doi:10.1016/j.atmosres.2008.04.004, 2008.

Shaw, S. L., Gantt, B., and Meskhidze, N.: Production and emissions of marine isoprene and monoterpenes: A review, Adv. Meteorol., 2010, 408696, doi:10.1155/2010/408696, 2010.

Skop, R. A., Viechnicki, J. T., and Brown, J. W.: A model for microbubble scavenging of surface-active lipid molecules from seawater, J. Geophys. Res.-Oceans, 99, 16395-16402, doi:10.1029/94JC01199, 1994.

Stefan, R. L. and Szeri, A. J.: Surfactant scavenging and surface deposition by rising bubbles, Journal of colloid and interface science, 212, 1-13, doi:10.1006/jcis.1998.6037, 1999.

Stier, P., Feichter, J., Kinne, S., Kloster, S., Vignati, E., Wilson, J., Ganzeveld, L., Tegen, I., Werner, M., Balkanski, Y., Schulz, M., Boucher, O., Minikin, A., and Petzold, A.: The aerosol-climate model ECHAM5-HAM, Atmos. Chem. Phys., 5, 1125-1156, doi:10.5194/acp-5-1125-2005, 2005.

Stokes, M. D., Deane, G. B., Prather, K., Bertram, T. H., Ruppel, M. J., Ryder, O. S., Brady, J. M., and Zhao, D.: A Marine Aerosol Reference Tank system as a breaking wave analogue for the production of foam and sea-spray aerosols, Atmos. Meas. Tech., 6, 1085-1094, doi:10.5194/amt-6-1085-2013, 2013.

Stokes, R. and Robinson, R.: Interactions in aqueous nonelectrolyte solutions. I. Solute-solvent equilibria, The Journal of Physical Chemistry, 70, 2126-2131, doi:10.1021/j100879a010, 1966.

Sultana, C. M., Collins, D. B., and Prather, K. A.: The Effect of Structural Heterogeneity in Chemical Composition on Online Analysis of Sea Spray Aerosol Particles, in preparation, 2016.

Tseng, R. S., Viechnicki, J. T., Skop, R. A., and Brown, J. W.: Sea-to-air transfer of surface-active organic compounds by bursting bubbles, J. Geophys. Res.-Oceans, 97, 5201-5206, doi:10.1029/91JC00954, 1992.

Vaishya, A., Ovadnevaite, J., Bialek, J., Jennings, S. G., Ceburnis, D., and O'Dowd, C. D.: Bistable effect of organic enrichment 
on sea spray radiative properties, Geophys. Res. Lett., 40, 63956398, doi:10.1002/2013GL058452, 2013.

Vesna, O., Sjogren, S., Weingartner, E., Samburova, V., Kalberer, M., Gäggeler, H. W., and Ammann, M.: Changes of fatty acid aerosol hygroscopicity induced by ozonolysis under humid conditions, Atmos. Chem. Phys., 8, 4683-4690, doi:10.5194/acp-84683-2008, 2008.

Wang, X., Sultana, C. M., Trueblood, J., Hill, T. C. J., Malfatti, F., Lee, C., Laskina, O., Moore, K. A., Beall, C. M., McCluskey, C. S., Cornwell, G. C., Zhou, Y., Cox, J. L., Pendergraft, M. A., Santander, M. V., Bertram, T. H., Cappa, C. D., Azam, F., DeMott, P. J., Grassian, V. H., and Prather, K. A.: Microbial control of sea spray aerosol composition: A tale of two blooms, ACS Central Science, 1, 124-131, doi:10.1021/acscentsci.5b00148, 2015.

Wiedensohler, A., Birmili, W., Nowak, A., Sonntag, A., Weinhold, K., Merkel, M., Wehner, B., Tuch, T., Pfeifer, S., Fiebig, M., Fjäraa, A. M., Asmi, E., Sellegri, K., Depuy, R., Venzac, H., Villani, P., Laj, P., Aalto, P., Ogren, J. A., Swietlicki, E., Williams, P., Roldin, P., Quincey, P., Hüglin, C., Fierz-Schmidhauser, R., Gysel, M., Weingartner, E., Riccobono, F., Santos, S., Grüning, C., Faloon, K., Beddows, D., Harrison, R., Monahan, C., Jennings, S. G., O’Dowd, C. D., Marinoni, A., Horn, H.-G., Keck, L., Jiang, J., Scheckman, J., McMurry, P. H., Deng, Z., Zhao, C. S., Moerman, M., Henzing, B., de Leeuw, G., Löschau, G., and Bastian, S.: Mobility particle size spectrometers: harmonization of technical standards and data structure to facilitate high quality long-term observations of atmospheric particle number size distributions, Atmos. Meas. Tech., 5, 657-685, doi:10.5194/amt5-657-2012, 2012.
Wise, M. E., Surratt, J. D., Curtis, D. B., Shilling, J. E., and Tolbert, M. A.: Hygroscopic growth of ammonium sulfate/dicarboxylic acids, J. Geophys. Res.-Atmos., 108, D204638, doi:10.1029/2003jd003775, 2003.

Zhang, X., Massoli, P., Quinn, P. K., Bates, T. S., and Cappa, C. D.: Hygroscopic growth of submicron and supermicron aerosols in the marine boundary layer, J. Geophys. Res.-Atmos., 119, 83848399, doi:10.1002/2013JD021213, 2014.

Zhao, W. X., Hopke, P. K., and Prather, K. A.: Comparison of two cluster analysis methods using single particle mass spectra, Atmos. Environ., 42, 881-892, doi:10.1016/j.atmosenv.2007.10.024, 2008. 